\title{
The petrological and geochemical characteristics of an ophiolite volcanic suite from the Ghayth area of Oman
}

\author{
Durair A'SHAIKH ${ }^{*}$, Sumio MiYASHITA ${ }^{* *}$ and Hiroharu MATSUEDA ${ }^{* * *}$ \\ *Department of Earth and Planetary Sciences, Faculty of Science, Hokkaido University, \\ Sapporo 060-0810, Japan \\ *** Department of Geology, Niigata University, Niigata 950-2181, Japan \\ ${ }^{* * *}$ Hokkaido University Museum, Hokkaido University, Sapporo 060-0810, Japan
}

\begin{abstract}
The volcanic suite of the Ghayth area forms the lowermost lavas of the Oman ophiolite extrusives within Oman ophiolite. Ghayth area is located within Fizh block, one of the northern blocks of the Oman ophiolite. The lithological succession in the Ghayth area consists of Units 1a and 1b (Geotimes Unit, Lasail Unit) overlain by Unit 2 (Clinopyroxene-phyric Unit). Texturally, Unit 1a lavas are dominantly aphyric, with few plagioclase and clinopyroxene clots and microphenocrysts. In contrast, Unit $1 \mathrm{~b}$ lavas are sparsely to moderately phyric with clinopyroxene, plagioclase (altered to albite) and olivine pseudomorphs (replaced by clay minerals) in subophitic texture in intersertal-intergranular groundmass consisting of albite laths and devitrified mesostasis (altered to clay minerals). Unit 2 lavas are glomerophyritic with clinopyroxene and olivine (pseudomorphed by calcite) glomerocrysts surrounded by plagioclase microlites and devitrified mesostasis (partly altered to calcite).

The minor elements data from clinopyroxenes indicate those Units 1a, $1 \mathrm{~b}$ and 2 showing tholeiitic basalt signatures but with island arc affinities for Unit 2. However, the triangular discrimination diagram of $\left(\mathrm{Y}^{-} \mathrm{La}^{-}\right.$ $\mathrm{Nb}$ ) for bulk analyses indicated that Units $1 \mathrm{a}$ and $1 \mathrm{~b}$ are falling where the three fields of $\mathrm{N}-\mathrm{MORB}$ (Normal Mid Ocean Ridge Basalt), back arc basin basalt and island arc tholeiite all meet. The clinopyroxenes and bulk chemical compositions of Unit 1a lavas are more evolved and are characterized by enrichment of incompatible HFSEs, REEs (High Field Strength Elements, Rare Earth Elements) and depletion of $\mathrm{Cr}$ and $\mathrm{Ni}$ relative to the less evolved Unit $\mathrm{lb}$ lavas (which are richer in $\mathrm{Cr}$ and $\mathrm{Ni}$ and low in HFSEs and REEs abundances). Correlations between $\mathrm{Mg \#} \mathrm{(Magnesium} \mathrm{number)} \mathrm{and} \mathrm{selected} \mathrm{major,} \mathrm{minor} \mathrm{and} \mathrm{trace} \mathrm{element} \mathrm{concentrations}$ indicate their single mantle sources with different magmatic fractionation events. The spider diagram patterns of selected bulk rock trace elements show that Units $1 \mathrm{a}$ and $1 \mathrm{~b}$ have a pattern of mixed affinities between $\mathrm{N}^{-}$ MORB and back-arc basin. This is coupled with the $\mathrm{Nb} / \mathrm{Ta}$ and $\mathrm{Zr} / \mathrm{Hf}$ depletions relative to $\mathrm{N}-\mathrm{MORB}$ and the mildly depleted to flat LREE patterns, indicating that their mantle sources are possibly contaminated with back-arc basin signatures. Therefore, these lavas might have erupted in the back-arc spreading center.
\end{abstract}

Keywords: Oman ophiolite extrusives, Normal Mid Ocean Ridge, Back arc Basin basalt

\section{INTRODUCTION}

It is widely accepted that ophiolite complexes formed in a variety of tectonic settings (e.g., fast- and slow-spreading mid-ocean ridges, island arcs, back-arc basins) although we do not have the opportunity to observe modern examples of ophiolite emplacement. Ideally, the tectonic setting for an ancient ophiolite complex may be ascertained by studying its present geological setting, its internal structure, the timing of emplacement, the nature and prove-

H. Matsueda, matsueda@museum.hokudai.ac.jp Corresponding author nance of overlying sedimentary rocks, and its igneous geochemistry (Pearce et al., 1984). The igneous geochemistry of volcanic rocks has been widely used because processes within subduction zones are believed to impart diagnostic geochemical signatures to supra-subduction zone (SSZ) basalts that are distinct from those of midocean ridge basalts (MORBs). Compared to MORBs, lavas formed near a subduction zone are selectively enriched in alkali and alkaline earth metals and other incompatible elements (e.g., Sr, K, Rb, Ba, Th) and relatively depleted in high field-strength elements (e.g., Ta, Nb, Hf, Zr, Ti) (Pearce et al., 1984; Gill, 1981; Plank and 
Langmuir, 1993).

These chemical signatures have been variously attributed to modification of the mantle source region of arc basalts by a subduction component derived from ocean sediments and altered ocean crust, transferred by melts or fluids derived from the subducted slab. This geochemical process includes selective retention of high field-strength elements in the subducting slab (Plank and Langmuir, 1998). There are many lines of evidence that some ancient ophiolite complexes formed above a subduction zone. On the other hand, Indian Ocean Ridge basalts are a special case of spreading that sampled depleted mantle sources and, in some parts of the ridge system, showing enrichment by the oceanic plateau (hot ${ }^{-}$ spot) (Mahoney et al., 1995; Doucet et al., 2004). Thus, supra-subduction zone and Indian Ocean basalts may show similar trace element systematics in terms of their mantle sources, indicating both prior depletion and enrichment processes. They differ in their mantle sources. Indian ocean basalts are contaminated with plume-mantle sources (Mahoney et al., 1995) while supra-subduction zone basalts are characterized by an influence of arc signatures, HFSEs (High Field Strength Elements) depletions with LILEs (Large Ion Lithophile Elements) enrichments.

The Oman ophiolite is one member of the long chain of Tethyan ophiolites that extend from the western Mediterranean to Southeast Asia and from the late Jurassic to the early Cretaceous period. Mineralogical and geochemical studies have shown that there are important differences along the Tethyan ophiolite belt. The Oman ophiolite forms a huge thrust sheet that is over $600 \mathrm{~km}$ long, up to $150 \mathrm{~km}$ wide, and between 5 and $10 \mathrm{~km}$ thick. It crops out over an area of about $20000 \mathrm{~km}^{2}$ along the length of the Oman Mountains from near Dibba in the north to near Sur in the southeast (Lippard et al., 1986). This ophiolite was disrupted into sixteen contiguous tectonic blocks while being thrust over the Arabian Platform (Beurrier, 1987). The main lithological units noted by Lippard et al. (1986) are: 'tectonite peridotite mantle', 'gabbro and

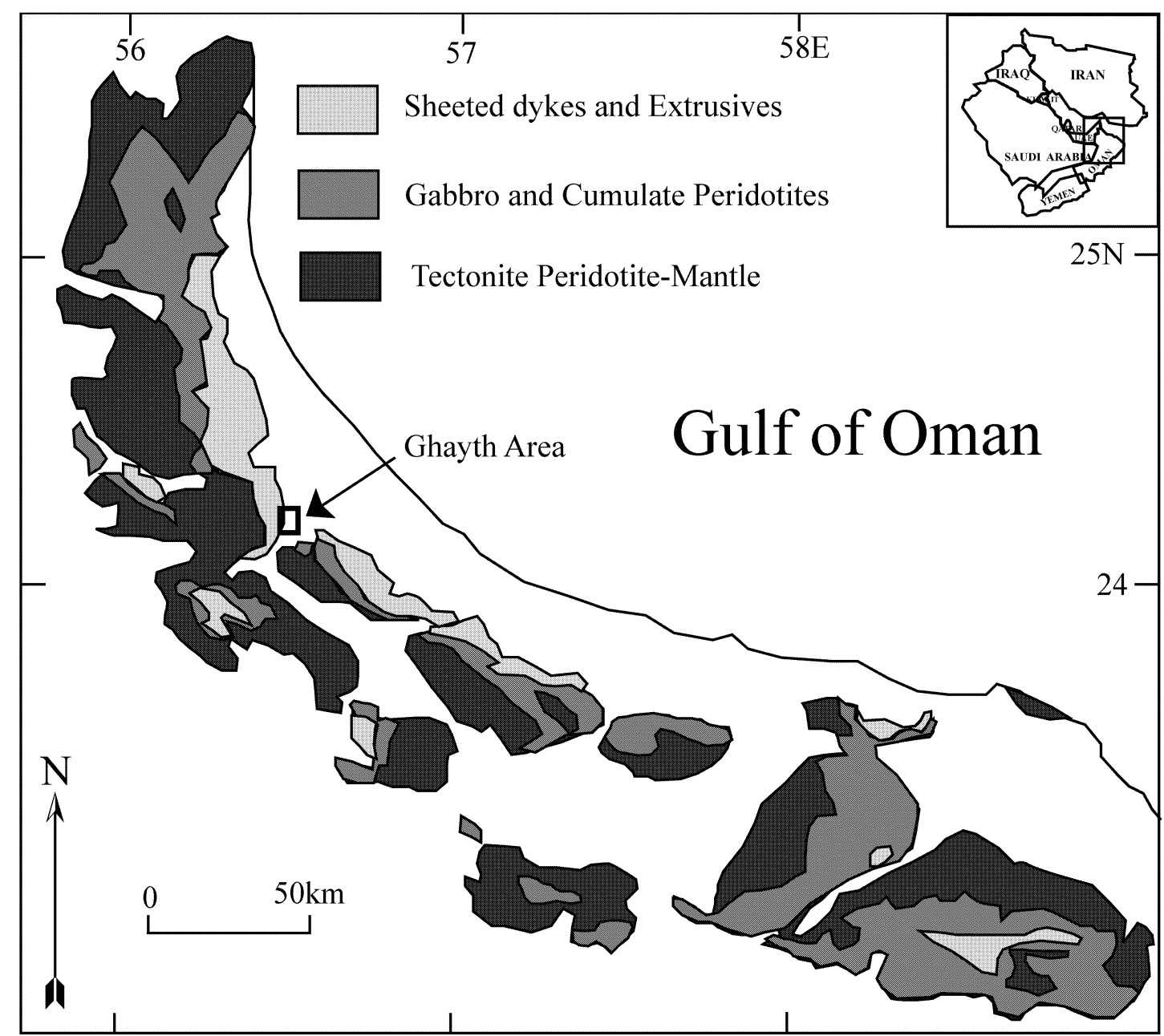

Figure 1. Simplified geologic map of Northern Oman Mountains ophiolite (Lippard et al., 1986) and location of the study area. 


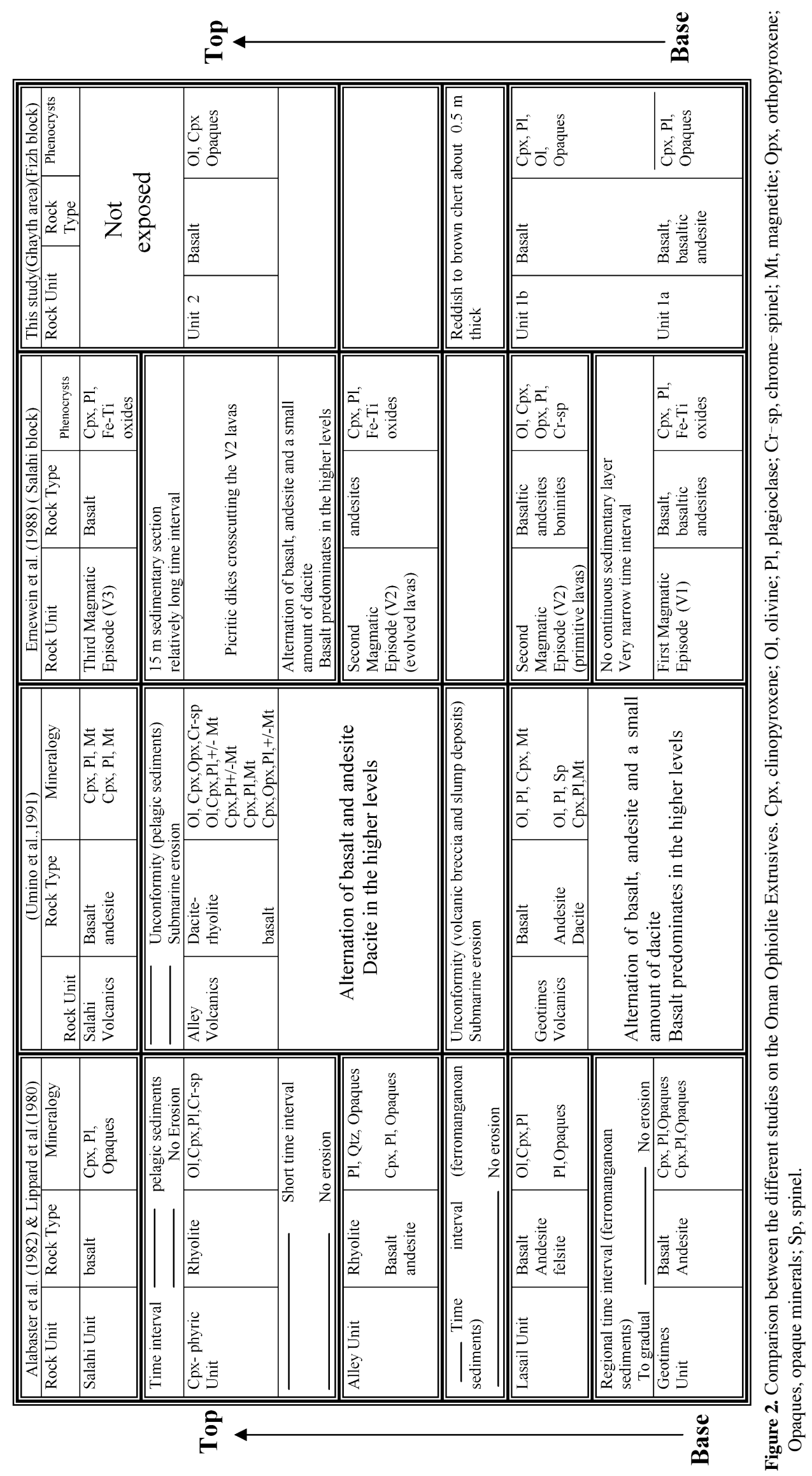


cumulate sequence' to 'sheeted dykes and extrusives' (Fig. 1). The lavas in this ophiolite are diverse geochemically including MORB (Mid Ocean Ridge Basalt) or BABB (Back Arc Basin Basalt), island arc tholeiites and calcalkaline series lavas (Pearce et al., 1981; Alabaster et al., 1982; Lippard et al., 1986; Ernewein et al., 1988; Umino et al., 1990; Rochette et al., 1991; Ishikawa et al., 2002; Adachi et al., 2003; Einaudi et al., 2003; Godard et al., 2003) as illustrated in Figure 2. Therefore, Alabaster et al. (1982) and Lippard et al. (1986) suggested that the Geotimes Unit formed at a spreading axis over a suprasubduction mantle source, the Lasail Unit formed in seamount spreading centers, the Alley and the $\mathrm{Cpx}$-phyric Units are island arc tholeiites which formed in arc magmatism while the uppermost Salahi Unit formed in intraplate magmatism. On the other hand, Ernewein et al. (1988) suggested that V1 volcanism (Geotimes Unit) initiated in the N-MORB while, V2 (Alley and Cpx-phyric Units) formed by intra-oceanic volcanism, but V3 (Salahi Unit) formed by intra-plate seamount magmatism.

The study of the extrusives sequences is essential in establishing the genesis of the Oman ophiolite in terms of magmatic and tectonic settings. We will refer to these upper lava units as the Oman ophiolite extrusives. However, the study of the primary characteristics of the extrusives is complicated by controversial interpretations because of seafloor alteration superimposed on probable magmatic source heterogeneities.

\section{ANALYTICAL METHODS}

Major and minor and trace element compositions of the lavas were analyzed by XRF (Rigaku RIX 3000 of Niigata University). The analytical method is after Takahashi and Shuto (1997). Samples were carefully selected, excluding veins and weathered parts. Lava samples were analyzed using the geostandard sample JB-1 to monitor the analytical accuracy. Representative data of major and trace elements, by XRF, of Units $1 \mathrm{a}$ and $1 \mathrm{~b}$ are illustrated in Table 1. Trace elements of lavas were analyzed by ICP-MS at Acme Analytical Laboratories Inc, Vancouver, Canada. The analytical accuracies are variable from element to element; for example, $\mathrm{Au}: 0.5 \mathrm{ppb}, \mathrm{Yb}$ : 0.05 and Lu: 0.01. Details on analytical methods and

Table 1. Major and trace element chemistries in Units $1 \mathrm{a}$ and $1 \mathrm{~b}$ (XRF analysis)

\begin{tabular}{|c|c|c|c|c|c|c|c|c|c|c|}
\hline \multirow[b]{2}{*}{ Major oxides( wt.\%) } & \multicolumn{2}{|l|}{ Unit 1a } & \multicolumn{7}{|c|}{ Unit $1 b$} & \multirow[b]{2}{*}{ GM115L } \\
\hline & GM150 & GM156 & GM164 & GM167 & GM170 & GM107L & GM108 & JM110L & GM112L & \\
\hline $\mathrm{SiO}_{2}$ & 56.02 & 56.38 & 58.95 & 54.62 & 54.14 & 48.78 & 47.74 & 46.91 & 48.98 & 48.02 \\
\hline $\mathrm{TiO} 2$ & 1.44 & 1.79 & 1.21 & 1.76 & 1.83 & 1.15 & 1.1 & 1.11 & 1.13 & 0.56 \\
\hline $\mathrm{Al}_{2} \mathrm{O}_{3}$ & 14.53 & 16.4 & 14.98 & 14.56 & 14.16 & 14.46 & 14.01 & 13.95 & 13.1 & 15.94 \\
\hline $\mathrm{FeO}^{(\mathrm{t})}$ & 10.22 & 9.67 & 8.79 & 11.64 & 12.46 & 9.08 & 9.11 & 8.63 & 7.79 & 7.67 \\
\hline Mno & 0.25 & 0.14 & 0.2 & 0.25 & 0.2 & 0.15 & 0.17 & 0.15 & 0.19 & 0.11 \\
\hline $\mathrm{MgO}$ & 3.57 & 2.34 & 3.56 & 4.29 & 4.14 & 5.49 & 5.58 & 5.24 & 5.85 & 8.96 \\
\hline $\mathrm{CaO}$ & 3.47 & 2.59 & 2.77 & 2.59 & 4.01 & 10.91 & 11.84 & 13.32 & 10.92 & 9.37 \\
\hline $\mathrm{Na}_{2} \mathrm{O}$ & 6.12 & 8.12 & 6.62 & 6.16 & 5.93 & 4.63 & 4.5 & 4.26 & 4.57 & 3.62 \\
\hline $\mathrm{K}_{2} \mathrm{O}$ & 0.56 & 0.17 & 0.05 & 0.06 & 0.17 & 0.09 & 0.07 & 0.06 & 1.1 & 0.18 \\
\hline $\mathrm{P}_{2} \mathrm{O}_{5}$ & 0.18 & 0.17 & 0.17 & 0.17 & 0.15 & 0.1 & 0.1 & 0.1 & 0.1 & 0.04 \\
\hline LOI & 3.40 & 2.16 & 2.92 & 3.73 & 2.71 & 5.49 & 6.23 & 6.78 & 6.67 & 6.03 \\
\hline Total & 99.76 & 99.93 & 100.22 & 99.83 & 99.90 & 100.33 & 100.45 & 100.51 & 100.40 & 100.50 \\
\hline \multicolumn{11}{|l|}{ Trace elements( $\mathrm{ppm})$} \\
\hline $\mathrm{Ba}$ & 84.1 & 7.1 & 1.2 & nd & 24.9 & 11.1 & 7 & 2.2 & 194.4 & 30.2 \\
\hline $\mathrm{Cr}$ & 14.3 & 13.4 & 19.7 & 20.2 & 14.7 & 139.4 & 142.9 & 149 & 155.3 & 286 \\
\hline $\mathrm{Rb}$ & 4.2 & 0.3 & - & 0.1 & 1.6 & - & 8.88 & 0.56 & - & - \\
\hline V & 217 & 367 & 140.3 & 344.3 & 456.8 & 265.6 & 277 & 268.5 & 259 & 189 \\
\hline $\mathrm{Ni}$ & 6.5 & nd & 7.9 & 12 & 5.4 & 48.6 & 54.5 & 90.8 & 52.1 & 53.7 \\
\hline $\mathrm{Sr}$ & 105 & 78 & 47.2 & 45.7 & 92.1 & 53.3 & 195 & 410.2 & 72.7 & 64.2 \\
\hline $\mathrm{Nb}$ & 3.4 & 2.1 & 1.6 & 2.9 & 3.5 & 2.3 & 0.48 & 1.4 & 2.4 & 2.8 \\
\hline Y & 40.6 & 38.4 & 38.4 & 42.5 & 36.9 & 29 & 18.801 & 16.5 & 29.5 & 29.8 \\
\hline $\mathrm{Zr}$ & 124 & 112.3 & 120.6 & 122.8 & 108.2 & 75.3 & 45.7 & 37.9 & 78.9 & 78.3 \\
\hline $\mathrm{Mg \#}$ & 0.38 & 0.30 & 0.42 & 0.40 & 0.37 & 0.52 & 0.52 & 0.52 & 0.57 & 0.68 \\
\hline
\end{tabular}

- Below detection limit. 
Table 2. Trace elements chemistries with total carbon and

\begin{tabular}{|c|c|c|c|c|c|c|}
\hline \multirow[b]{2}{*}{ Trace elements (ppm) } & \multicolumn{2}{|l|}{ Unit 1a } & \multicolumn{3}{|c|}{ Unit $1 b$} & \multirow[b]{2}{*}{ GM112L } \\
\hline & GM156 & GM161 & GM170 & GM107L & GM110L & \\
\hline $\mathrm{Ba}$ & 7.1 & 17.9 & 22.1 & 2.9 & $2.2(\mathrm{XRF})$ & 207 \\
\hline Co & 34.2 & 23.3 & 45.5 & 43.8 & 43.4 & 70.9 \\
\hline $\mathrm{Ga}$ & 15.6 & 18.9 & 16.8 & 12.9 & 13.9 & 11.4 \\
\hline $\mathrm{Hf}$ & 2.7 & 3.3 & 3.2 & 1.7 & 2 & 2 \\
\hline $\mathrm{Nb}$ & 1.8 & 2.3 & 1.9 & 1.5 & 1.6 & 1.3 \\
\hline $\mathrm{Rb}$ & 1.3 & - & 0.8 & 0.6 & - & 6.3 \\
\hline $\mathrm{Sn}$ & 1 & - & 1 & - & - & - \\
\hline $\mathrm{Sr}$ & 66.1 & 53.2 & 79.9 & 79.4 & 55.3 & 95.3 \\
\hline $\mathrm{Ta}$ & 0.1 & 0.2 & 0.2 & 0.1 & 0.1 & - \\
\hline Th & 0.3 & 0.5 & 0.3 & 0.2 & 0.3 & 0.4 \\
\hline $\mathrm{U}$ & 1.3 & 0.2 & - & 0.3 & 0.2 & 0.1 \\
\hline V & 313 & 138 & 395 & 258 & 276 & 272 \\
\hline W & 102 & 49.7 & 83.4 & 77.5 & 48 & 85 \\
\hline $\mathrm{Zr}$ & 86.6 & 118 & 86.6 & 62.4 & 63.9 & 61.9 \\
\hline $\mathrm{Y}$ & 32.9 & 37.8 & 31.5 & 25 & 25.8 & 25 \\
\hline $\mathrm{La}$ & 4 & 4.6 & 3.6 & 2.8 & 2.9 & 2.8 \\
\hline $\mathrm{Ce}$ & 12.1 & 14.5 & 11.2 & 8.5 & 9.1 & 9.1 \\
\hline $\mathrm{Pr}$ & 1.8 & 2.3 & 1.8 & 1.3 & 1.3 & 1.3 \\
\hline $\mathrm{Nd}$ & 8.8 & 14.4 & 11 & 7.7 & 7.8 & 8 \\
\hline $\mathrm{Sm}$ & 3.3 & 4.1 & 3.2 & 2.6 & 2.6 & 2.7 \\
\hline $\mathrm{Eu}$ & 1.1 & 1.3 & 1.2 & 0.88 & 0.99 & 0.89 \\
\hline $\mathrm{Gd}$ & 5.3 & 6.1 & 5.5 & 3.9 & 3.8 & 4 \\
\hline $\mathrm{Tb}$ & 0.87 & 1.1 & 0.89 & 0.7 & 0.72 & 0.64 \\
\hline Dy & 4.9 & 5.7 & 5.4 & 4 & 3.76 & 4 \\
\hline Ho & 1.15 & 1.4 & 1.2 & 0.96 & 0.94 & 0.94 \\
\hline $\mathrm{Er}$ & 3.4 & 3.9 & 3.5 & 2.8 & 2.5 & 2.6 \\
\hline $\mathrm{Tm}$ & 0.45 & 0.57 & 0.47 & 0.37 & 0.35 & 0.34 \\
\hline $\mathrm{Yb}$ & 3.3 & 3.8 & 3.4 & 2.2 & 2.5 & 2.6 \\
\hline $\mathrm{Lu}$ & 0.44 & 0.56 & 0.45 & 0.33 & 0.34 & 0.36 \\
\hline Total Carbon & 0.06 & 0.43 & 0.15 & 0.81 & 1.2 & 1.3 \\
\hline Total Sulfur & 0.01 & 0.02 & 0.02 & 0.01 & 0.02 & 0.02 \\
\hline
\end{tabular}

- Below detection limit.

accuracy can be referred to in a PDF file in the homepage of the laboratory: (http://www.acmelab.com). Representative analyses of trace elements are illustrated in Table 2. Clinopyroxenes of Units $1 \mathrm{a}, 1 \mathrm{~b}$ and 2 were analyzed by wavelength dispersive electron microprobe analyzer JXA-8600SX (JEOL) at Niigata University. Analytical conditions were: probe current $1.3 \times 10^{-8} \mathrm{~A}$; accelerating voltage of $15 \mathrm{kV}$. Integration time is 30 seconds for each measurement. Eleven elements ( $\mathrm{Si}, \mathrm{Ti}, \mathrm{Al}, \mathrm{Cr}, \mathrm{Fe}$, $\mathrm{Ni}, \mathrm{Mn}, \mathrm{Mg}, \mathrm{Ca}, \mathrm{Na}$ and $\mathrm{K}$ ) were analyzed and corrected by the oxide-ZAF method. Representative EPMA analyses are presented in Table 3.

\section{OMAN OPHIOLITE EXTRUSIVES IN NORTHERN OMAN MOUNTAINS AND THE STUDY AREA}

These extrusives, which overlie the sheeted dyke complex, are up to $2000 \mathrm{~m}$ thick in the most exposed section of the pillowed basaltic lavas, with minor andesitic to rhyolitic extrusives. These extrusives are cut by basic to acidic hypabyssal intrusives (Lippard et al., 1986). The extrusives show different eruptive events coupled with their different mantle source heterogeneities.

\section{Ghayth area}

This area is well exposed, with different morphologies from pillow lavas to massive flows. The Ghayth area was first surveyed by Mitsubishi Materials Natural Resources Development Corporation (formerly Bishimetal Exploration Company) in 1984. It is located about $3 \mathrm{~km}$ from the abandoned Aarja mine and $3 \mathrm{~km}$ northeast of the plant site of the Oman Mining Company. It is located in the Fizh block (Fig. 1).

\section{Outlines of geology}

The lavas in this area are oriented $\mathrm{N}-\mathrm{S}$ in strike, dipping moderately to the east. Diorite intrudes in the western vicinity of the area (Fig. 3). Large gossans appear near the 
sulfur in Units 1a and 1b (ICP-MS analysis)

\begin{tabular}{|c|c|c|c|c|c|c|}
\hline \multirow[b]{2}{*}{ Trace elements (ppm) } & \multicolumn{2}{|l|}{ Unit 1a } & \multicolumn{3}{|c|}{ Unit $1 b$} & \multirow[b]{2}{*}{ GM112L } \\
\hline & GM156 & GM161 & GM170 & GM107L & GM110L & \\
\hline Mo & 0.2 & 0.3 & 0.2 & 0.1 & 0.1 & 0.1 \\
\hline $\mathrm{Cu}$ & 3.2 & 57.1 & 33.5 & 54.8 & 53.8 & 52.3 \\
\hline $\mathrm{Pb}$ & 0.7 & 0.9 & 1.1 & 0.8 & 0.8 & 1 \\
\hline $\mathrm{Zn}$ & 76 & 72 & 65 & 56 & 52 & 44 \\
\hline $\mathrm{Ni}$ & 1.6 & 8.6 & 5.5 & 29.7 & 32.9 & 49 \\
\hline As & 0.6 & $<.5$ & 0.5 & 1.7 & 1.7 & 0.6 \\
\hline $\mathrm{Cd}$ & 0.1 & 0.1 & 0.1 & 0.2 & 0.2 & 0.2 \\
\hline $\mathrm{Sb}$ & 0.2 & 0.1 & - & - & - & - \\
\hline $\mathrm{Bi}$ & - & - & - & - & - & - \\
\hline $\mathrm{Ag}$ & - & - & - & - & - & - \\
\hline $\mathrm{Au}$ & 1.6 & 2 & 2.5 & 2.5 & 2.6 & 1.7 \\
\hline $\mathrm{Hg}$ & - & - & - & 0.02 & 0.01 & 0.01 \\
\hline $\mathrm{Tl}$ & - & - & - & - & - & - \\
\hline $\mathrm{Se}$ & - & 0.5 & - & - & - & 0.6 \\
\hline Total carbon (wt \%) & 0.06 & 0.43 & 0.15 & 0.81 & 1.22 & 1.28 \\
\hline Total sulphur (wt \%) & 0.01 & 0.02 & 0.02 & 0.01 & 0.02 & 0.02 \\
\hline
\end{tabular}

- Below detection limit.

Table 3. Representative clinopyroxene chemistries in Units 1a, $1 \mathrm{~b}$ and 2 (EPMA analysis)

\begin{tabular}{|c|c|c|c|c|c|c|c|c|}
\hline \multicolumn{3}{|c|}{ Unit 1a } & \multirow[b]{2}{*}{ GM27-R } & \multirow[b]{2}{*}{ GM27-R } & \multirow[b]{2}{*}{ GM27-R } & \multicolumn{3}{|c|}{ Unit $1 b$} \\
\hline Sample No. & GM27-R & GM27-C & & & & GM27-R & GM112L-C & GM112L-C \\
\hline $\mathrm{SiO}_{2}$ & 49.863 & 49.533 & 50.29 & 49.163 & 50.958 & 49.841 & 51.309 & 51.577 \\
\hline $\mathrm{TiO}_{2}$ & 0.956 & 1.344 & 1.071 & 1.379 & 1.015 & 1.267 & 0.781 & 0.722 \\
\hline $\mathrm{Al}_{2} \mathrm{O}_{3}$ & 3.203 & 3.917 & 3.392 & 3.902 & 3.243 & 3.581 & 3.293 & 3.604 \\
\hline $\mathrm{Cr}_{2} \mathrm{O}_{3}$ & 0.016 & 0.02 & 0.048 & 0.004 & 0.107 & 0.048 & 0 & 0.209 \\
\hline $\mathrm{FeO}$ & 10.94 & 11.781 & 11.038 & 10.856 & 10.679 & 11.038 & 7.617 & 6.528 \\
\hline $\mathrm{MnO}$ & 0.247 & 0.294 & 0.226 & 0.195 & 0.209 & 0.193 & 0.144 & 0.21 \\
\hline $\mathrm{MgO}$ & 14.612 & 14.474 & 14.824 & 14.484 & 15.597 & 14.273 & 16.022 & 16.635 \\
\hline $\mathrm{CaO}$ & 18.61 & 18.408 & 18.992 & 18.853 & 18.685 & 19.52 & 19.562 & 19.269 \\
\hline $\mathrm{Na}_{2} \mathrm{O}$ & 0.332 & 0.326 & 0.333 & 0.326 & 0.322 & 0.355 & 0.265 & 0.254 \\
\hline Total & 98.78 & 100.10 & 100.21 & 99.16 & 100.82 & 100.12 & 98.99 & 99.01 \\
\hline $\mathrm{Ca}$ & 39.2 & 38.6 & 39.4 & 39.7 & 38.3 & 40.7 & 40.9 & 40.6 \\
\hline $\mathrm{Mg}$ & 42.8 & 42.2 & 42.8 & 42.4 & 44.5 & 41.4 & 46.6 & 48.7 \\
\hline $\mathrm{Fe}$ & 18 & 19.3 & 17.9 & 17.8 & 17.1 & 17.9 & 12.4 & 10.7 \\
\hline $\mathrm{Mg \#}$ & 0.704 & 0.686 & 0.705 & 0.704 & 0.722 & 0.698 & 0.79 & 0.819 \\
\hline $\mathrm{Si}$ & 1.891 & 1.861 & 1.881 & 1.859 & 1.888 & 1.87 & 1.91 & 1.908 \\
\hline $\mathrm{Al}$ & 0.143 & 0.173 & 0.15 & 0.174 & 0.142 & 0.158 & 0.144 & 0.157 \\
\hline $\mathrm{Ti}$ & 0.03 & 0.04 & 0.03 & 0.04 & 0.03 & 0.036 & 0.022 & 0.02 \\
\hline $\mathrm{Cr}$ & 0 & 0.001 & 0.001 & 0 & 0.003 & 0.001 & 0 & 0.006 \\
\hline $\mathrm{Fe}$ & 0.347 & 0.37 & 0.345 & 0.343 & 0.331 & 0.346 & 0.237 & 0.202 \\
\hline $\mathrm{Mn}$ & 0.008 & 0.009 & 0.007 & 0.006 & 0.007 & 0.006 & 0.005 & 0.007 \\
\hline $\mathrm{Mg}$ & 0.826 & 0.81 & 0.826 & 0.816 & 0.861 & 0.798 & 0.889 & 0.917 \\
\hline $\mathrm{Ca}$ & 0.756 & 0.741 & 0.761 & 0.764 & 0.741 & 0.785 & 0.78 & 0.764 \\
\hline $\mathrm{Na}$ & 0.024 & 0.024 & 0.024 & 0.024 & 0.023 & 0.026 & 0.019 & 0.018 \\
\hline Total & 4.022 & 4.027 & 4.025 & 4.025 & 4.024 & 4.026 & 4.006 & 3.999 \\
\hline
\end{tabular}


center of the area, trending $\mathrm{N}-\mathrm{S}$ over a $450 \mathrm{~m}$ length. The lava sequence is subdivided into Units $1 \mathrm{a}, 1 \mathrm{~b}$ and 2 . The Unit 1a consists predominantly of massive flows in alternation with pillow lavas (Fig. 3). The pillows are mostly large tubes, often over $3 \mathrm{~m}$ in length and up to $1.5 \mathrm{~m}$ in diameter. The pillow interiors and massive flows have intersertal to sub-ophitic textures whereas pillow margins exhibit quench skeletal and variolitic textures. The Unit 1a lavas are non-vesicular at the base to slightly vesicular at the top. Unit $1 \mathrm{~b}$ is interlayered conformably in Unit 1a. The Unit 2 lavas show similar field colors and morphologies as Unit 1, which makes it difficult to distinguish them in the field. However, the Unit 2 lavas are the most fresh of all lava exposures. They show very limited exposed outcrops with brownish large-sized pillows. The estimated proportion of the massive $(68 \%)$ and pillow lava flows $(32 \%)$ in a section along a transect $(\mathrm{A}-\mathrm{B})$ from the base to the top of Unit 1 (1150 $\mathrm{m}$ in thickness) (Fig. 3) is indicative of its formation at a fast spreading ridge setting, analogous to that observed at $12^{\circ} 50^{\prime} \mathrm{N}$ of the East Pacific Rise (Bonatti and Harrison, 1988).

\section{MICROSCOPIC MINERALOGY}

The identification of the igneous textures and magmatic mineral phases were traced in these lavas because of limited alteration effects. Samples from Unit 1a are aphyric with occasional appearances of plagioclase and clinopyroxene microphenocrysts as clots in groundmass (Fig. 4A, $\mathrm{B}) . \mathrm{Fe}$-oxides in the groundmass are altered to goethite. Unit 1a shows cryptocrystalline variolitic texture with radiating acicular albitized plagioclase laths. This texture is typical of rapidly cooled oceanic lavas. Sub-ophitic texture can also be observed in some samples (Fig. 4B) where some clinopyroxene clots are surrounded by intersertal groundmass of albitized plagioclase laths and altered devitrified glass. In contrast, Unit $1 \mathrm{~b}$ lavas exhibit holocrystalline sub-ophitic to porphyritic textures of clinopyroxene crystals surrounded by intergranular to occasional intersertal groundmass of plagioclase lath-like crystals and occasional devitrified glass (Fig. 4C, D). Unit $1 \mathrm{~b}$ shows few to common clinopyroxene, plagioclase (altered to albite) and olivine (altered to clay minerals)

Table 3. (Continued.)

\begin{tabular}{|c|c|c|c|c|c|c|c|c|c|}
\hline \multicolumn{10}{|c|}{ Unit 2} \\
\hline GM112L-R & GM115L-C & GM115L-C & GM115L-R & GM3-C & GM3-C & GM3-R & GM4-C & GM4-C & GM4-R \\
\hline 51.56 & 53.071 & 54.09 & 52.291 & 52.859 & 53.99 & 54.303 & 53.585 & 53.766 & 54.149 \\
\hline 0.915 & 0.268 & 0.218 & 0.33 & 0.087 & 0.072 & 0.038 & 0.159 & 0.131 & 0.13 \\
\hline 2.658 & 3.124 & 1.86 & 3.349 & 2.157 & 1.441 & 1.695 & 2.252 & 2.189 & 2.261 \\
\hline 0.068 & 0.258 & 0.19 & 0.674 & 0.357 & 0.309 & 0.403 & 0.32 & 0.357 & 0.944 \\
\hline 10.399 & 4.611 & 3.795 & 4.232 & 3.513 & 3.098 & 3.564 & 3.503 & 3.624 & 3.302 \\
\hline 0.196 & 0.094 & 0.072 & 0.017 & 0.103 & 0.025 & 0.064 & 0.153 & 0.139 & 0.075 \\
\hline 14.638 & 17.862 & 18.293 & 17.563 & 18.277 & 18.499 & 18.733 & 18.281 & 18.241 & 18.577 \\
\hline 19.043 & 21.277 & 21.904 & 21.339 & 21.529 & 21.814 & 21.464 & 21.573 & 21.441 & 21.306 \\
\hline 0.308 & 0.196 & 0.18 & 0.191 & 0.13 & 0.129 & 0.129 & 0.137 & 0.152 & 0.159 \\
\hline 99.79 & 100.76 & 100.60 & 99.99 & 99.01 & 99.38 & 100.39 & 99.96 & 100.04 & 100.90 \\
\hline 40.1 & 42.8 & 43.5 & 43.5 & 43.3 & 43.7 & 42.7 & 43.4 & 43.2 & 42.9 \\
\hline 42.8 & 50 & 50.6 & 49.8 & 51.2 & 51.5 & 51.8 & 51.1 & 51.1 & 52 \\
\hline 17.1 & 7.2 & 5.9 & 6.7 & 5.5 & 4.8 & 5.5 & 5.5 & 5.7 & 5.2 \\
\hline 0.715 & 0.874 & 0.895 & 0.881 & 0.902 & 0.914 & 0.903 & 0.903 & 0.9 & 0.909 \\
\hline 1.926 & 1.919 & 1.953 & 1.906 & 1.939 & 1.967 & 1.96 & 1.945 & 1.95 & 1.944 \\
\hline 0.117 & 0.133 & 0.079 & 0.144 & 0.093 & 0.062 & 0.072 & 0.096 & 0.094 & 0.096 \\
\hline 0.026 & 0.007 & 0.006 & 0.009 & 0.002 & 0.002 & 0.001 & 0.004 & 0.004 & 0.004 \\
\hline 0.002 & 0.007 & 0.005 & 0.019 & 0.01 & 0.009 & 0.011 & 0.009 & 0.01 & 0.027 \\
\hline 0.325 & 0.139 & 0.115 & 0.129 & 0.108 & 0.094 & 0.108 & 0.106 & 0.11 & 0.099 \\
\hline 0.006 & 0.003 & 0.002 & 0.001 & 0.003 & 0.001 & 0.002 & 0.005 & 0.004 & 0.002 \\
\hline 0.815 & 0.963 & 0.984 & 0.954 & 0.999 & 1.004 & 1.008 & 0.989 & 0.986 & 0.994 \\
\hline 0.762 & 0.824 & 0.847 & 0.833 & 0.846 & 0.851 & 0.83 & 0.839 & 0.833 & 0.82 \\
\hline 0.022 & 0.014 & 0.013 & 0.014 & 0.009 & 0.009 & 0.009 & 0.01 & 0.011 & 0.011 \\
\hline 4.001 & 4.009 & 4.004 & 4.009 & 4.009 & 3.999 & 4.001 & 4.003 & 4.002 & 3.997 \\
\hline
\end{tabular}




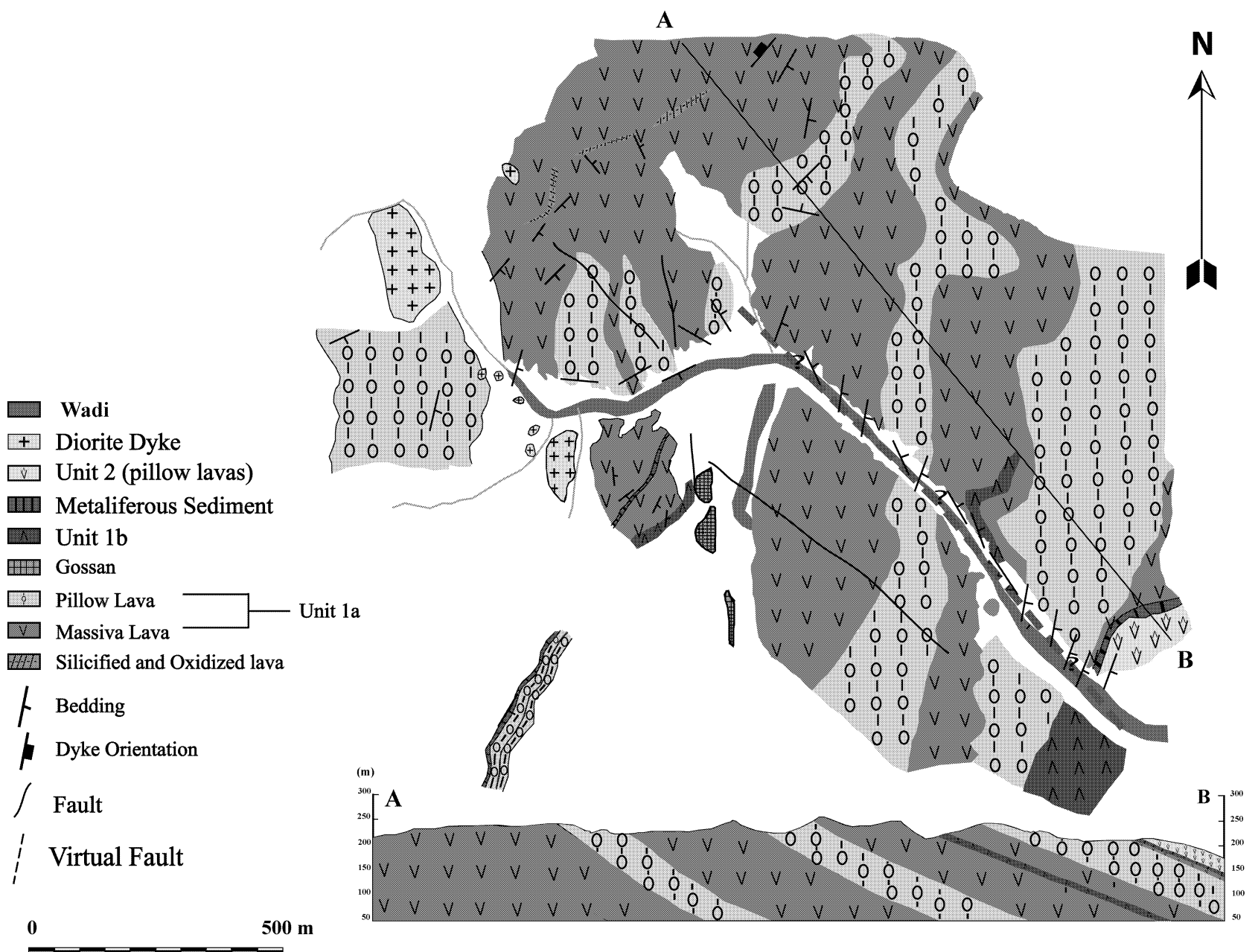

Figure 3. Geological map of Ghayth area and cross section (A-B) along the main transect of this area.

phenocrysts. Unit 2 shows clinopyroxene and pseudomorphic olivine phenocrysts to glomerocrysts in glomerophyric texture, which is enclosed by intersertal groundmass of plagioclase laths and devitrified glass (Fig. 4E, F).

\section{CLINOPYROXENE COMPOSITIONS}

Clinopyroxene phenocrysts and microlites are the only primary igneous mineral preserved throughout all the lava successions of the Oman ophiolite extrusives in this area. Clinopyroxenes of Units 1a plot in the augite field. Clinopyroxenes in Unit $1 \mathrm{~b}$ and 2 fall into the diopside to augite field (Fig. 5a).

The (Mg\#) (Magnesium number) in Unit 1a clinopyroxenes is lower than that of Unit $1 \mathrm{~b}$ clinopyroxenes. In comparison, the $\mathrm{Mg} \#$ in Unit 2 clinopyroxenes shows a more primitive composition compared to Unit 1 (Table 3) (Fig. 5b). In the meantime, the plots of Mg\# versus $\mathrm{Na}$ and $\mathrm{Ti}$ in the clinopyroxenes of the three units show that Unit 1a overlaps with the field of the Geotimes Unit, Unit
$1 \mathrm{~b}$ with the Lasail Unit and Unit 2 with the clinopyroxene-phyric Unit as the fields of the Geotimes, Lasail, Alley and clinopyroxene-phyric Units are taken from Alabaster et al. (1982).

On the other hand, use of Leterrier et al. (1982) diagrams has shown that Units $1 \mathrm{a}$ and $1 \mathrm{~b}$ clinopyroxenes have similar characteristics and plot in non-alkaline and non-orogenic fields, indicating the oceanic factor. In contrast, Unit 2 clinopyroxenes are non-alkaline, falling in the orogenic or arc field with island-arc tholeiite characteristics (Fig. 6).

\section{WHOLE ROCK CHEMISTRY}

The mineralogical and chemical compositions of the lava units in Ghayth area have been modified by low temperature hydrothermal alterations. Therefore, the evaluation of the geochemical features of these lavas should be made using the HFSE and REE (Rare earth element) contents, as they are not modified during secondary alterations. 

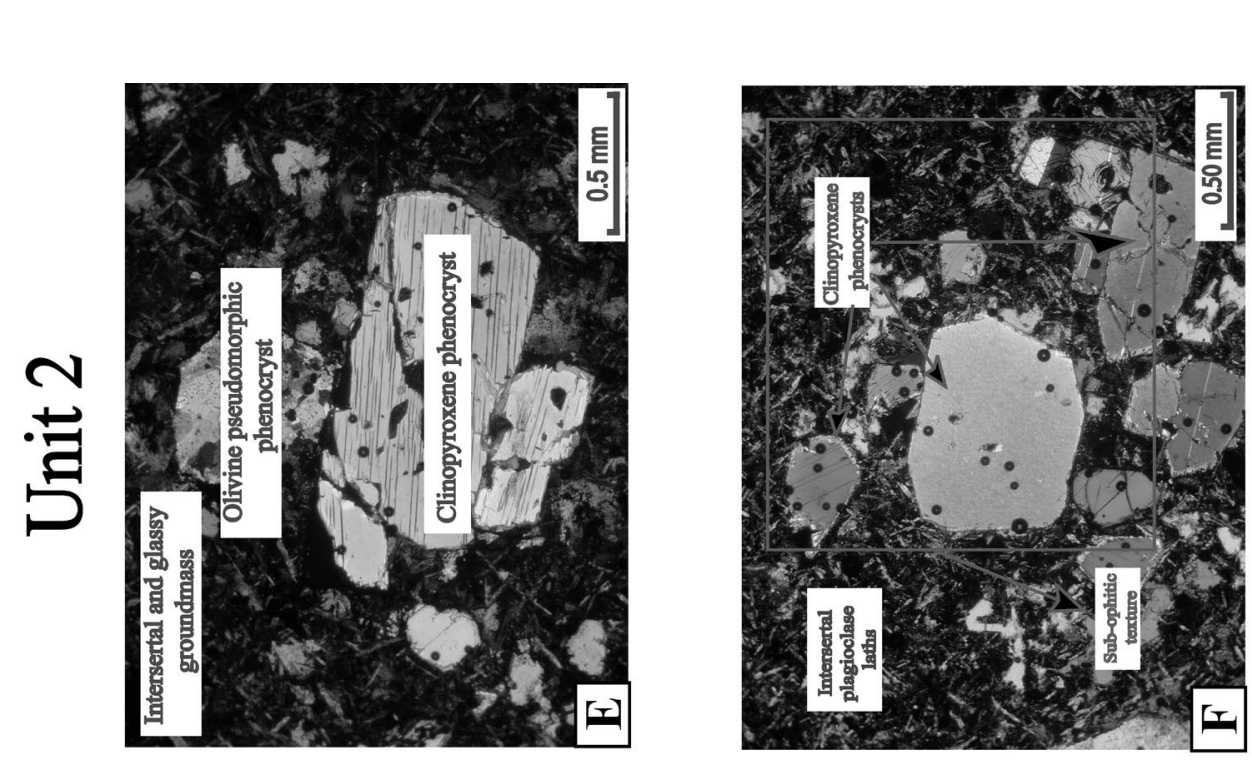

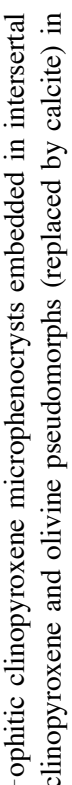
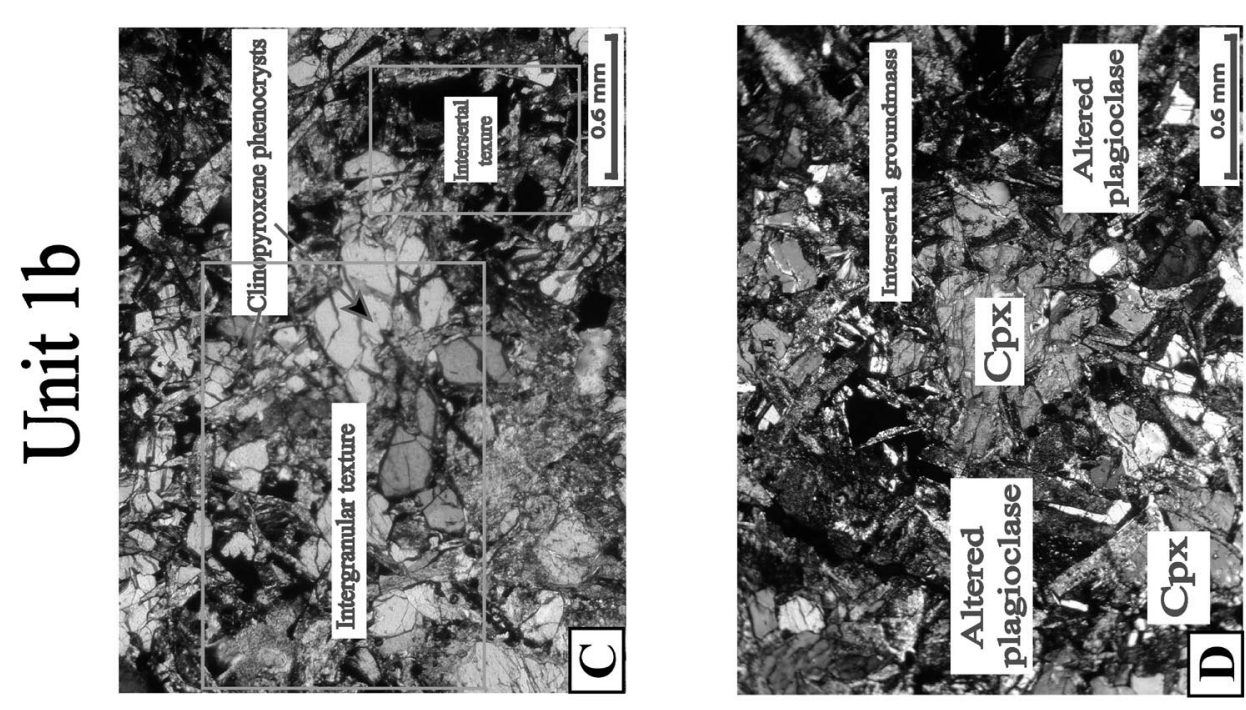

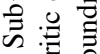

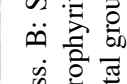
吾产 ठำ तु को 过 $\frac{\pi}{\Xi} \frac{\pi}{00}$ Ð

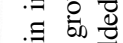

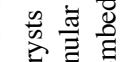
ठ정

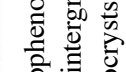

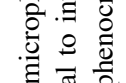
0

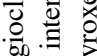
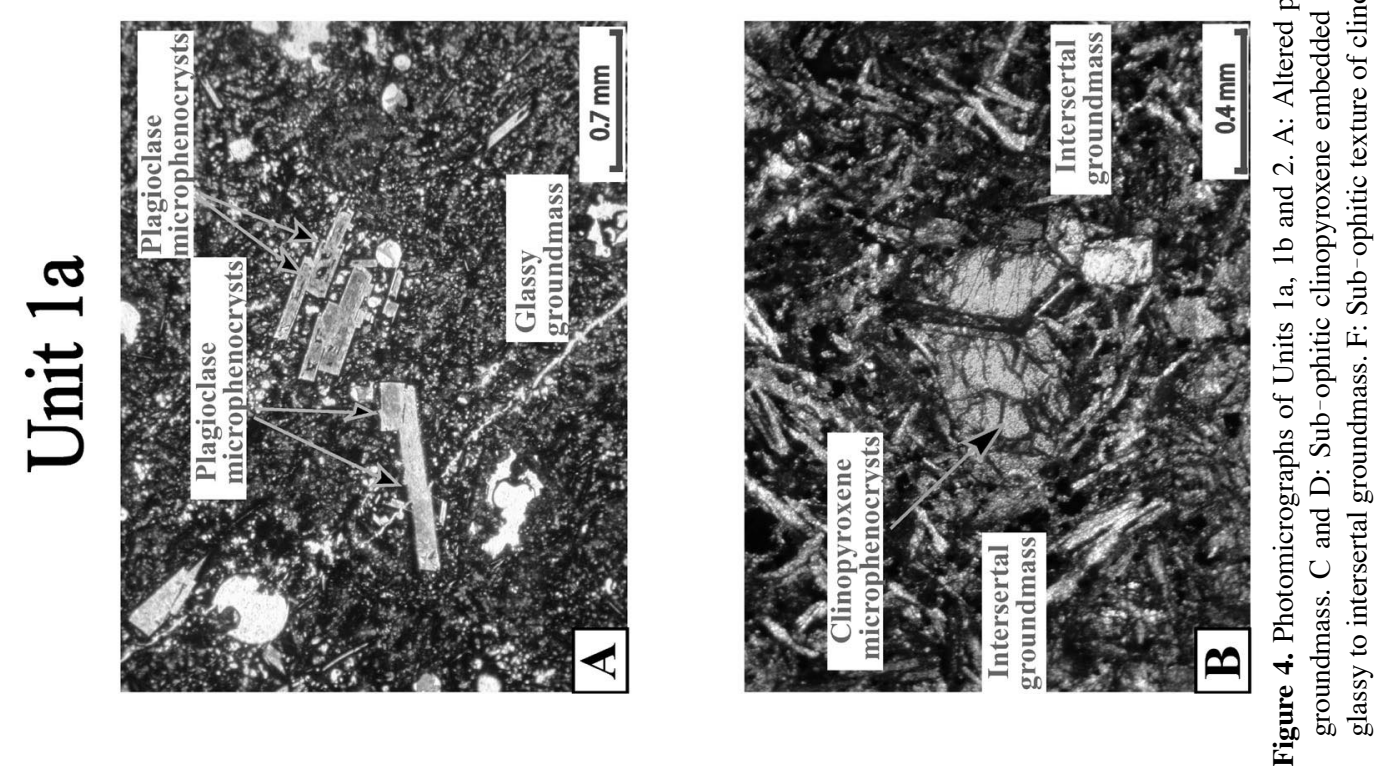


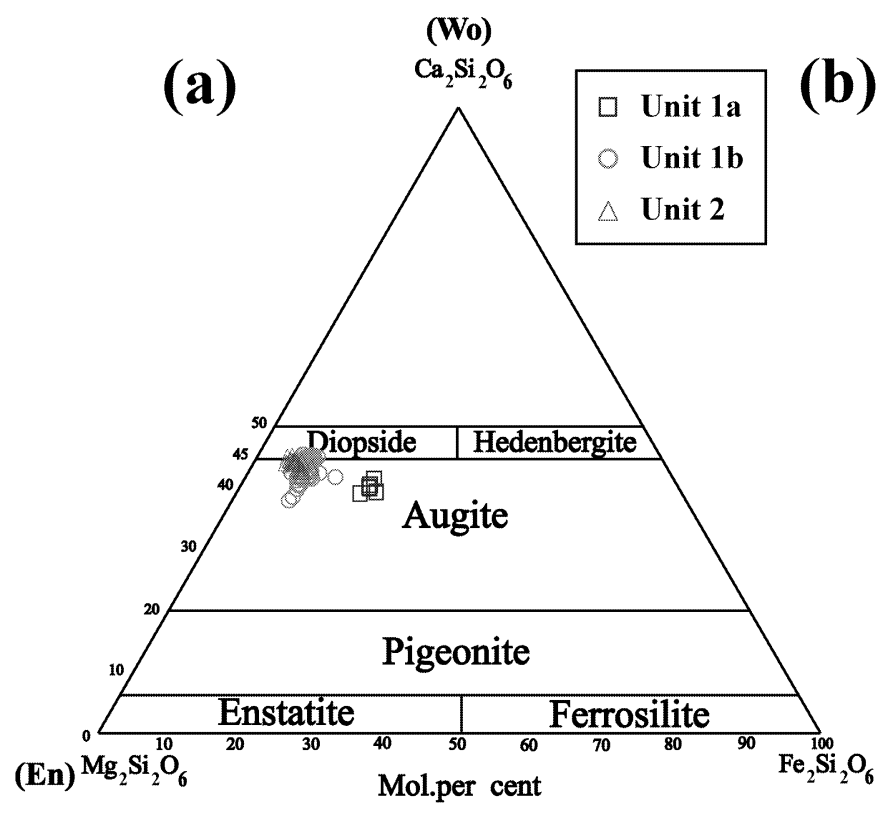

(b)

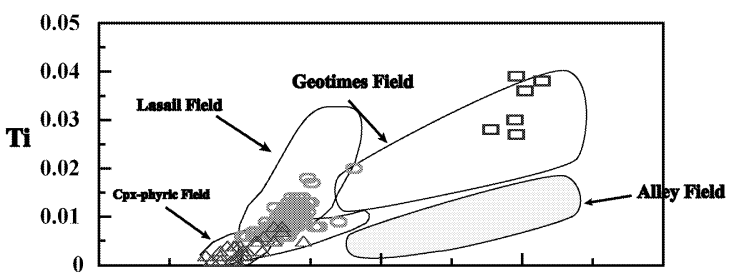

Figure 5. Clinopyroxene compositions of Units $1 \mathrm{a}, 1 \mathrm{~b}$ and 2. (a) The compositional ranges and nomenclature in a triangular diagram with Ca$\mathrm{Mg}$-Fe clinopyroxenes in Ghayth lavas (After Morimoto et al., 1988). (b) Fields for the Mg\# versus Ti and Na in the Geotimes, Lasail, Alley and Cpx-phyric Units after Alabaster et al. (1982) and compared to Units 1a, $1 \mathrm{~b}$ and 2.

\section{Fractionation trends in Units 1a and 1b}

The chemical analyses from the Units $1 \mathrm{a}$ and $1 \mathrm{~b}$ lavas analyzed in this study are presented in variation diagrams in Figures 7 and 8 using $\mathrm{Mg} \#[\mathrm{Mg} /(\mathrm{Mg}+\mathrm{Fe})]$ and $\mathrm{Zr}$ as the abscissae, respectively. They are compared with the data from the sheeted dyke complex from the Fizh block (Miyashita et al., 2003). The data plotted are recalculated to include LOI (loss on ignition i.e., $\mathrm{H}_{2} \mathrm{O}, \mathrm{CO}_{2}, \mathrm{SO}_{2}$ ). The compositions of the sheeted dike complex varies from relatively primary $(\mathrm{Mg} \#=0.7)$ to strongly fractionated $(\mathrm{Mg} \#$ $=0.35$ ) and the lavas cover a more evolved range with Unit 1a consisting entirely of fractionated lavas $(\mathrm{Mg \#}$ $<0.45)$ but with Unit $1 \mathrm{~b}$ being more primitive $(\mathrm{Mg} \#=$ $0.52-0.68)$.

The greater scatter of the data in the Units $1 \mathrm{a}$ and $1 \mathrm{~b}$ than for the sheeted dikes (Fig. 7) is attributed to secondary alterations and the following effects are inferred:

a) Significant $\mathrm{SiO}_{2}$ addition in Unit 1a; the apparently lower values of $\mathrm{SiO}_{2}$ in Unit $1 \mathrm{~b}$ relative to the sheeted dikes of similar $\mathrm{Mg \#}$ are attributed to dilution of $\mathrm{SiO}_{2}$ by $\mathrm{LOI}\left(\mathrm{H}_{2} \mathrm{O}+\mathrm{CO}_{2}\right)$.

b) Some mobility of $\mathrm{Al}_{2} \mathrm{O}_{3}$ in individual samples but no overall trend.

c) Loss of $\mathrm{Fe}$ in both Units $1 \mathrm{a}$ and $1 \mathrm{~b}$.

d) Little change in the $\mathrm{MgO}$ trend.

e) Loss of $\mathrm{CaO}$, particularly from Unit 1a; some enrichment of $\mathrm{CaO}$ in several group $1 \mathrm{~b}$ lavas.

f) Addition of $\mathrm{Na}$ in both Units $1 \mathrm{a}$ and $\mathrm{1b}$. g) No general pattern of $\mathrm{K}_{2} \mathrm{O}$ enrichment but some enrichment in several individual flows.

h) Possible small depletion in $\mathrm{TiO}_{2}, \mathrm{P}_{2} \mathrm{O}_{5}$ in Units 1a and $1 \mathrm{~b}$, which can be checked by plotting against Zr (Fig. 8).

i) Among trace elements, $\mathrm{Ni}$ and possibly $\mathrm{Cr}$ show some scattering, and $\mathrm{Zr}$ and $\mathrm{Nb}$ appear scattered in the fractionated Unit 1a lavas relative to equivalent sheeted dykes.

An alternate method of analysis is to plot $\mathrm{Zr}$ as an abscissa (Fig. 8) since this element is commonly thought to be immobile during secondary alteration. Therefore, the plots of $\mathrm{Zr}$ versus $\mathrm{TiO}_{2}, \mathrm{P}_{2} \mathrm{O}_{5}, \mathrm{Y}$ and $\mathrm{Nb}$ are well correlated. Both $\mathrm{Cr}$ and $\mathrm{Ni}$ are generally well correlated with $\mathrm{Zr}$, but $\mathrm{Cr}$ does not follow the coherent variation with $\mathrm{Zr}$, as shown by the sheeted dike complex samples.

The whole rock analyses suggest that HFSE and light, middle and heavy REE values of altered lavas may be concluded to be unchanged in relation to fresh samples.

\section{REE geochemistry}

The REEs show more fractionated patterns, in Unit 1a, and less fractionated patterns in Unit 1b (Fig. 9). Therefore, the REE patterns show more primitive lavas in Unit $1 \mathrm{~b}$ and more evolved ones in Unit 1a. Though the absolute concentrations are different, the REE patterns of these two units are in parallel, suggesting that these two 

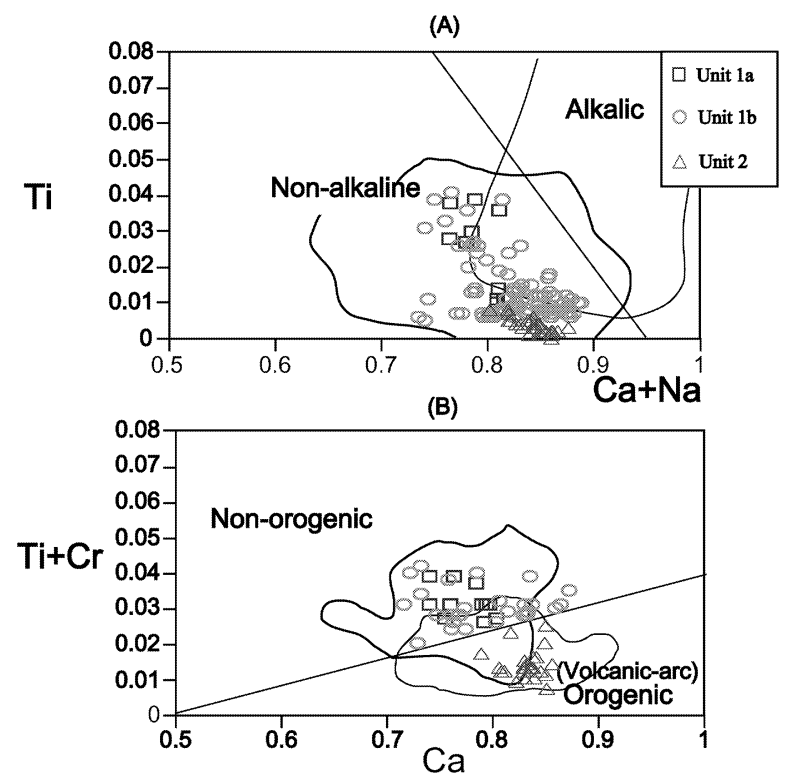

(C)

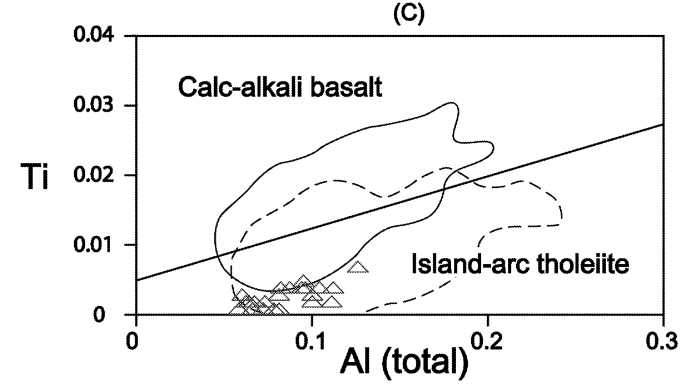

Figure 6. (A) $\mathrm{Ti}$ against $\mathrm{Ca}+\mathrm{Na}$ in clinopyroxene to discriminate alkaline to non-alkaline magmatic origin. (B) $\mathrm{Ti}+\mathrm{Cr}$ against $\mathrm{Ca}$ in clinopyroxene to discriminate orogenic to non-orogenic origin. (C) $\mathrm{Ti}$ against $\mathrm{Al}$ in clinopyroxene to discriminate the calc alkali basalt (Mature Subduction Zone) to Island-arc tholeiite (Young Subduction Zone). [After Leterrier et al. (1982)]

units are derived from same source. Generally, these lavas show mildly depleted to flat patterns with more anomalous negative Eu anomalies in Unit 1a than Unit $1 b$ (Fig. 9). Also, these patterns are similar to those in Lippard et al. (1986) and Godard et al. (2003), linking Unit 1a with Geotimes Unit and V1 lavas, and Unit $1 b$ with Lasail Unit and V2 (Type 1) lavas (Fig. 10).

\section{SUMMARIZED PETROLOGICAL AND GEOCHEMICAL VARIATIONS IN BOTH UNITS 1A AND 1B}

The petrography (clinopyroxene phenocrysts) and chemical compositions of Units $1 \mathrm{a}$ and $1 \mathrm{~b}$ provide clear evidence for pre-eruption crystallization and crystal fractionation. Knowledge of the crystallization of olivine tholeiite magmas permits the conclusion that olivine, plagioclase, augitic clinopyroxenes, sub-calcic pyroxenes, with one or more oxide phases are involved in low pressure evolution of primitive Unit $1 \mathrm{~b}(\mathrm{Mg} \#=70)$ to the evolved $(\mathrm{Mg} \#$ $=30$ ) lavas of Unit 1a.

\section{Unit 1a}

The lavas in this unit are more evolved, relatively phenocrysts-free. They are aphyric to occasionally sub-ophitic with clinopyroxene and plagioclase microphenocrysts embedded in intersertal albite laths and altered mesostasis. They are the most fractionated. They are enriched in incompatible HFSEs and REEs compared to Unit $1 \mathrm{~b}$. Also, they show depletions in compatible elements such as $\mathrm{Cr}$ and $\mathrm{Ni}$.

\section{Unit 1b}

The lavas in this unit are less evolved, sparsely to moderately phyric, with clinopyroxenes, altered plagioclase and altered olivine phenocrysts. They show sub-ophitic to porphyritic groundmass including intersertal albite. They show enrichments in compatible elements as $\mathrm{Cr}$ and $\mathrm{Ni}$ relative to Unit 1a lavas and depletion in incompatible HFSE and REE values.

\section{RESULTS AND DISCUSSION}

\section{Immobile trace elements compositions as tectonic envi- ronment indicators}

Pearce and Cann $(1971,1973)$ distinguished the geochemical signatures of rocks from volcanic arcs, the ocean floor (mid-ocean ridge), intra-plate settings and back-arc basins. When we study the altered igneous rocks, the relative proportions between the immobile trace element abundances can help to discriminate the tectonic environments in an efficient and generally accepted way. Figure 11a shows the tholeiitic rather than the alkalic character of both Units 1a and $1 \mathrm{~b}$ lavas by using the $\mathrm{Zr}$ versus $\mathrm{P}_{2} \mathrm{O}_{5}$ contents (rather than the conventional $\left(\mathrm{Na}_{2} \mathrm{O}\right.$ $+\mathrm{K}_{2} \mathrm{O}$ ) versus $\mathrm{SiO}_{2}$ since these oxides have been shown to be mobile during secondary alteration). Also, the triangular discrimination diagram of Figure $11 \mathrm{~b}$ is equivocal, with the Units 1a, 1b composition falling where the three fields of N-MORB, back-arc basin basalt and island arc tholeiite all meet.

\section{Relationship between HFSE and REE to indicate the arc signatures of lavas and their implications}

A supra-subduction zone (SSZ) ophiolite affinity would also explain the heterogeneity in mantle residues. Suprasubduction zone ophiolites are distinguished from MOR 


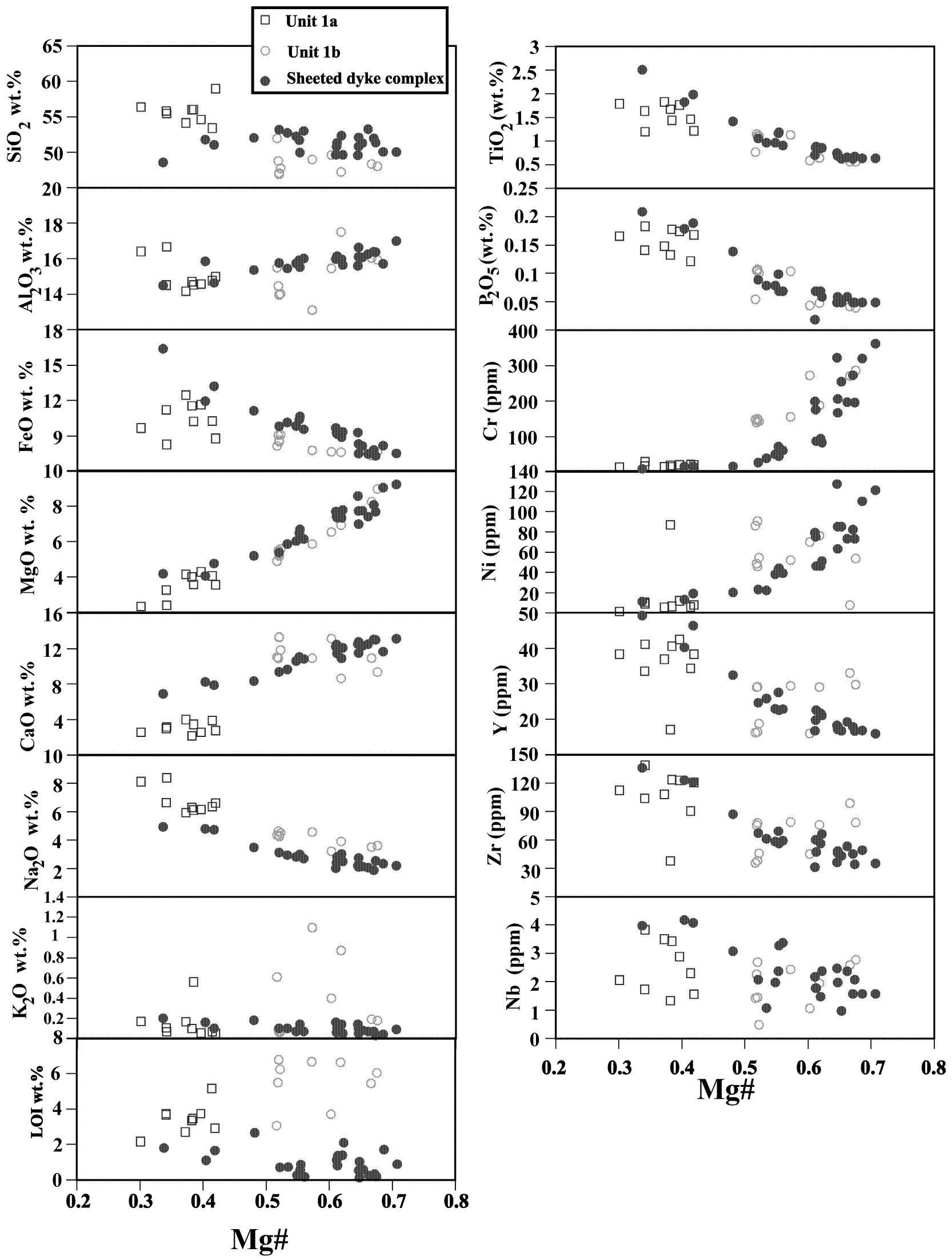

Figure 7. $\mathrm{Mg} \#$ versus other major and trace elements in Units $1 \mathrm{a}$ and $1 \mathrm{~b}$ in Ghayth area and compared with the compositions of the sheeted dyke complex after Miyashita et al. (2003). 

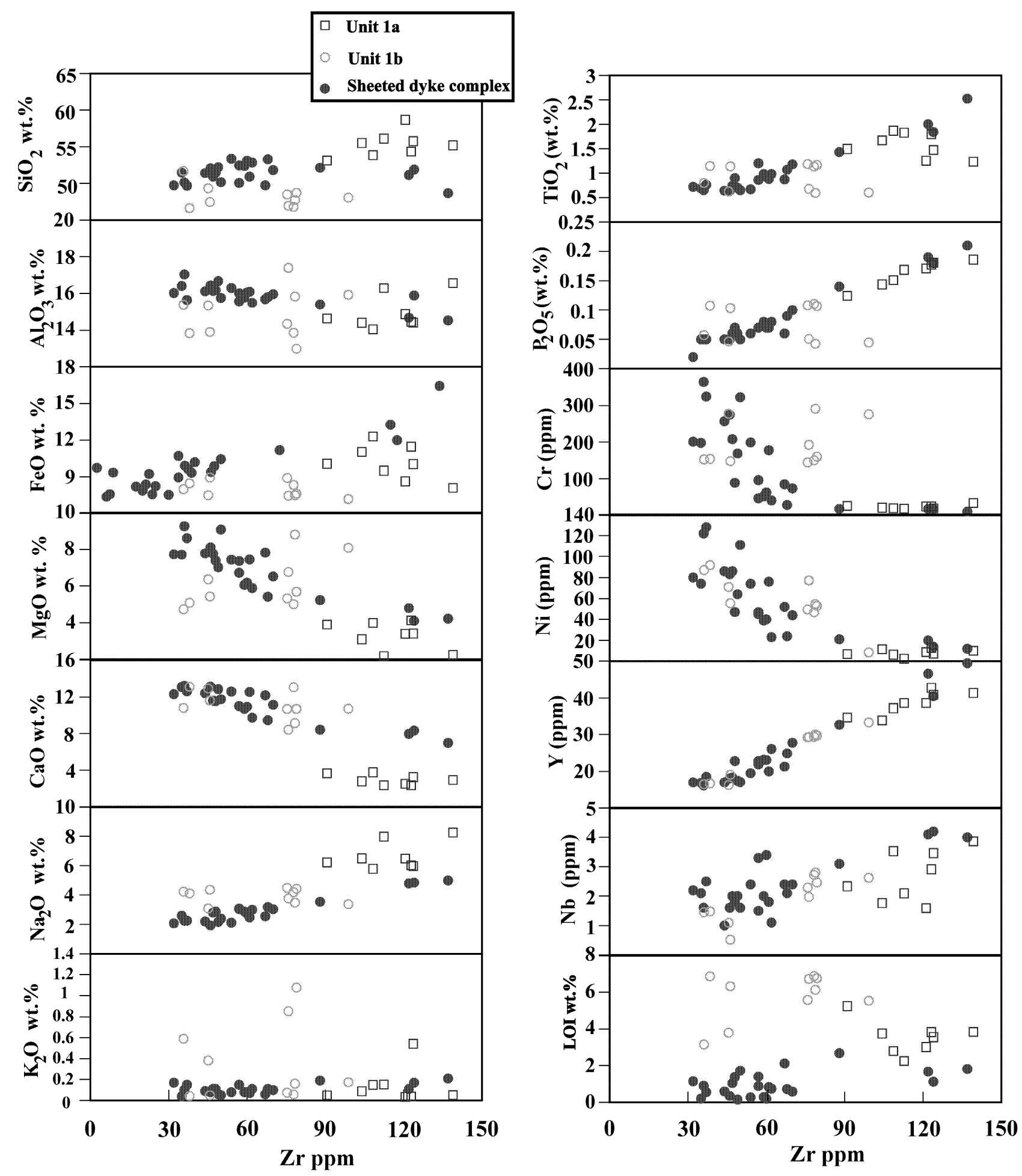

Figure 8. $\mathrm{Zr}$ versus other major and trace elements in Units 1a and 1b compared to Sheeted Dyke trends from Miyashita et al. (2003).

ophiolites by using their magma chemistry, igneous petrography, and regional geological constraints (Gillis and Banerjee, 2000). Supra-subduction zone ophiolites were formed in association with subduction, such as in the initiation of a back-arc basin, ridges as precursors to sub- duction, and ridge-trench intersections (Pearce et al., 1984). The magmatic chemistry of SSZ ophiolites shows evidence for the addition of mobile elements and water to the mantle source during the course of subduction and the melting of the previously depleted mantle sources (Pearce 


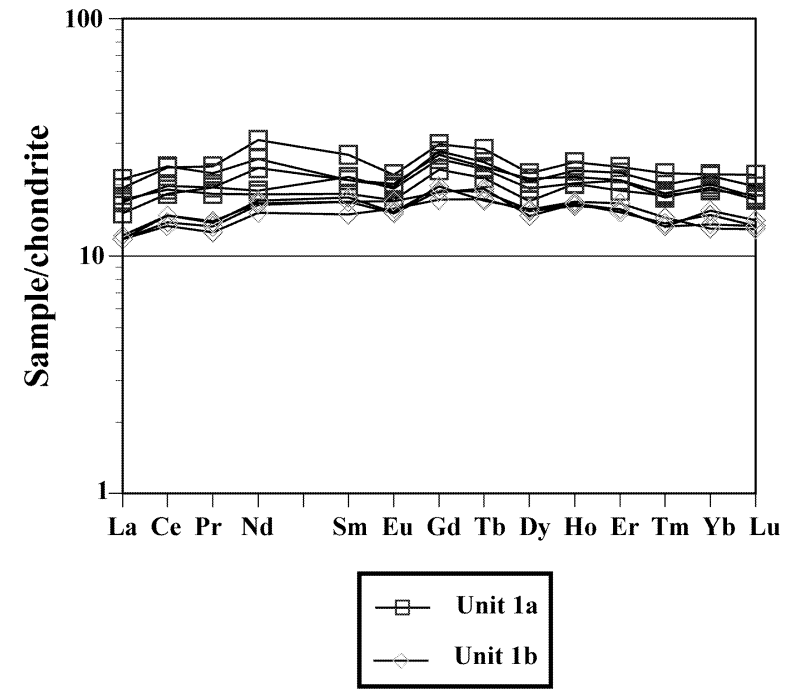

Figure 9. REE patterns in Units $1 \mathrm{a}$ and $1 \mathrm{~b}$ normalized to chondrites (After Sun and McDonough, 1989).

and Peate, 1995). There is much on-going debate about precisely which type of geotectonic setting many SSZ ophiolites represent. Because of this complexity, the chemical signatures may be interpreted by different models of the magmatic history of the lavas erupted at the upper part of the Oman ophiolite. The relationships between HFSE/REE, which have closely similar values of ionic radii, may reveal complexities in ophiolite environment of formation (Peate and Pearce, 1998). These elements are coherent in MORB genesis and fractionated relative to one another in SSZ magmatism. However, the Units $1 \mathrm{a}$ and $1 \mathrm{~b}$ compositions display HFSE/REE fractionation patterns that are interpreted as a result of the pre-conditioning of their mantle sources relative to $\mathrm{N}^{-}$ MORB sources. The Units $1 \mathrm{a}$ and $1 \mathrm{~b}$ display trace element compositions similar to $\mathrm{N}-\mathrm{MORB}$, except for $\mathrm{Nb}^{-}$ Ta, which has negative anomaly (Figs. 10, 12 and 13). Therefore, ratios such as $\mathrm{Nb} / \mathrm{Ta}$ show a range from 8-18 and, with depletions, compare to the N-MORB value of 17.6 (Sun and McDonough, 1989). Also, the values of $\mathrm{Zr} / \mathrm{Hf}$ ratios for these lavas are in the range of 26.6-35.9, indicating depleted values relative to the N-MORB values of 36.1 (Sun and McDonough, 1989).

\section{Comparisons of Units 1a and 1b to other tectonic envi- ronments}

A closer look at the HFSE values in Units $1 \mathrm{a}$ and $1 \mathrm{~b}$ indicates that they show relative depletions to N-MORB especially $\mathrm{Nb}$ and $\mathrm{Ta}$ (Table 2). As a comparison, the depletions in $\mathrm{Nb}$ and $\mathrm{Ta}$ were a result of a mantle that has experienced a previous melting episode, as in the North Chile Ridge example (Bach et al., 1996) (Fig. 13). The
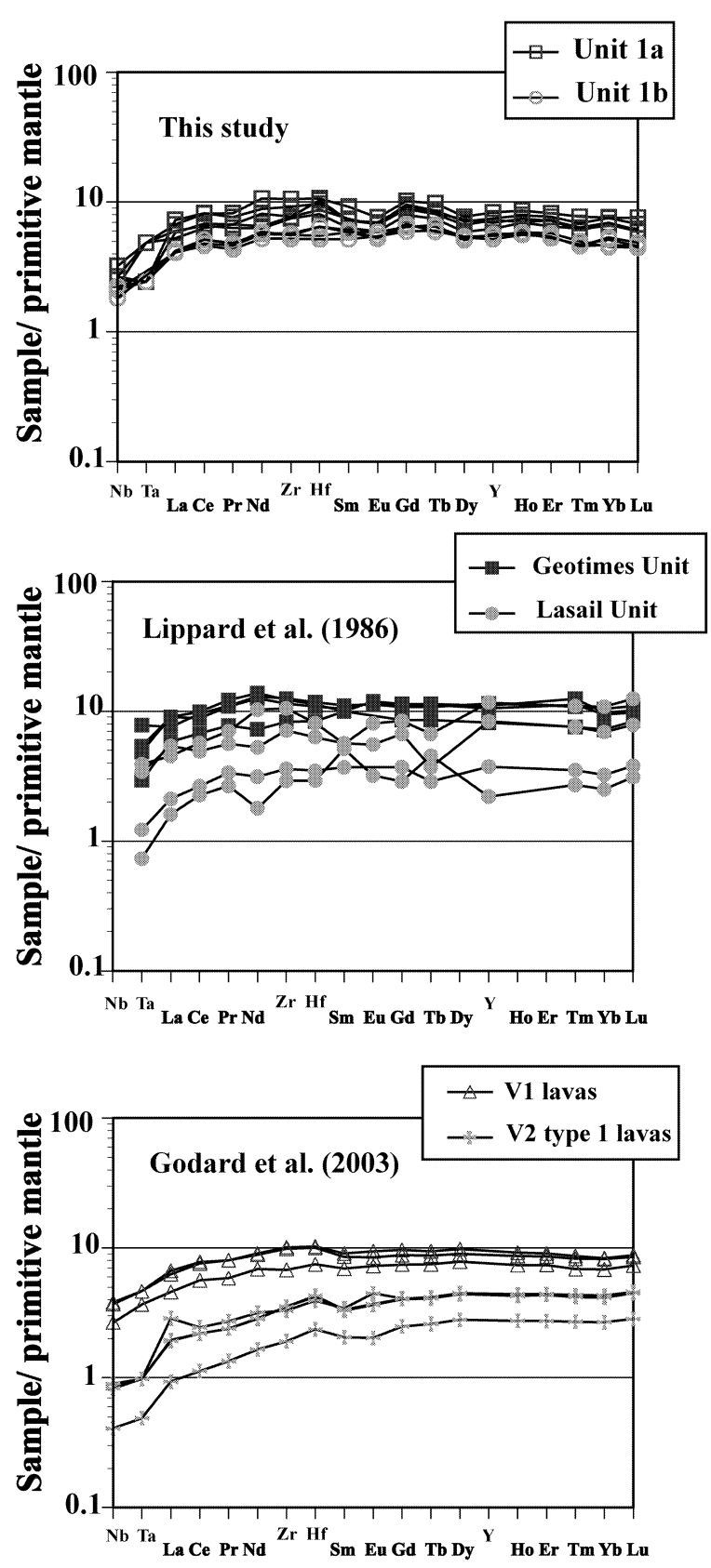

Figure 10. Trace element patterns normalized to primitive mantle (Sun and McDonough, 1989) of Units 1a and 1b of Ghayth area compared with patterns of the previous studies (Lippard et al., 1986; Godard et al., 2003).

previous melting episode is related to upwelling and melting of the mantle beneath the Pacific-Farallon ridge more than a million years ago. In contrast, the $\mathrm{Nb}$ and $\mathrm{Ta}$ depletions coupled with other HFSE depletions in the LauTonga back-arc and fore-arc basin basalts are related to contamination of their mantle source with fluid-rich melts (Ewart et al., 1994).

On the other hand, the trace elements patterns of Units $1 \mathrm{a}$ and $1 \mathrm{~b}$ are also correlated with the Indian Ocean 
(a)

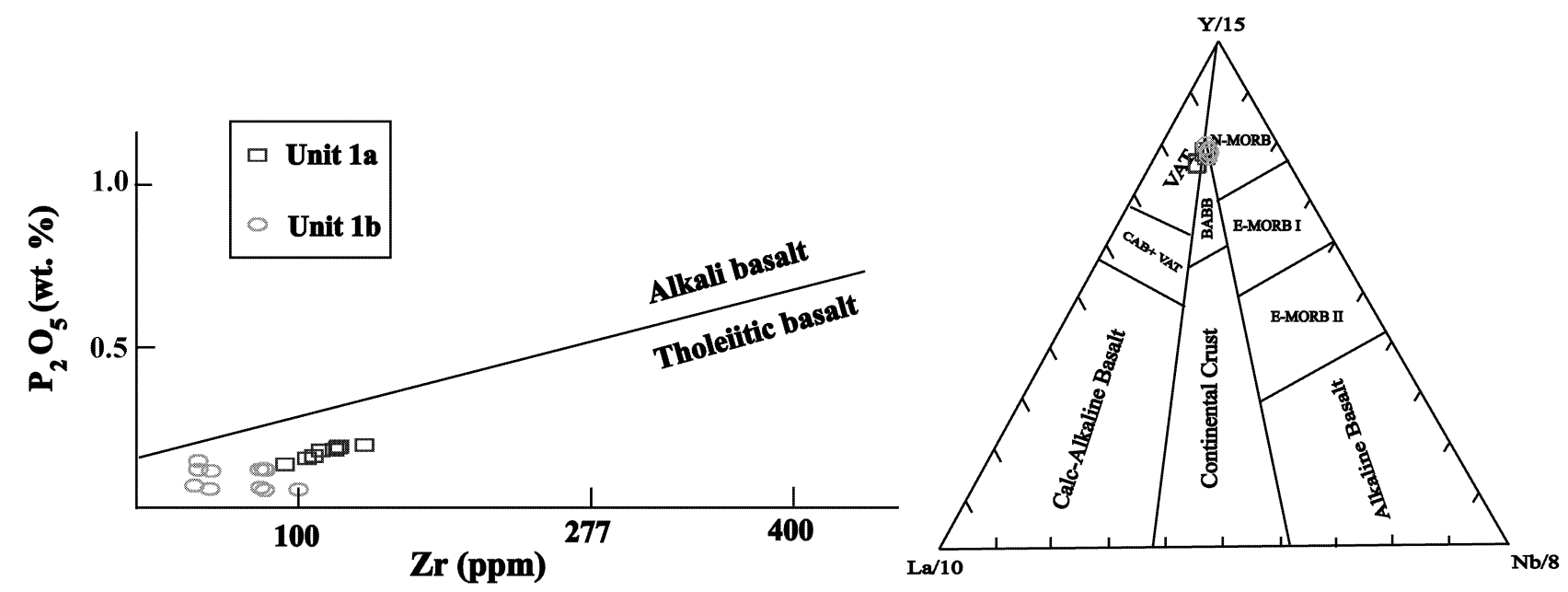

Figure 11. Discrimination diagrams for Units 1a and 1b using immobile elements in bi- and triangular diagrams (Winchester and Floyd, 1976; Cabanis and Lecolle, 1989).

basalts (Fig. 13). Thus, the wide range of trace element compositions of Ninetyeast Ridge lavas of the Indian Ocean is derived from binary mixing between depleted MORB and enriched Heard-Kerguelen plume mantle sources, as shown in Figure 13 (Frey et al., 1991). Also, the trace elements patterns of the Naturaliste Plateau in the Indian Ocean resemble the patterns of Units 1a and 1b. However, the source of the mildly depleted trace element patterns, coupled with $\mathrm{Nb}$ and $\mathrm{Ta}$ depletions in Naturaliste Plateau, are related to their mantle sources contaminated by the nearby rifted continental margin. On the other hand, the wide range of trace elements patterns from enriched to depleted in the West Valley segment of the Juan De Fuca Ridge are due to variably-melted mantle sources followed by mixing and/or fractionation in shallow level magma chambers.

\section{EVIDENCE FOR BACK-ARC BASIN VOLCANISM}

Several authors have developed different models for the formation of the Oman ophiolite extrusives. We will try to discuss every model and argue about them in terms of Units 1a and 1b. Alabaster et al. (1982) and Lippard et al. (1986) suggested that the Geotimes Unit formed over a supra-subduction mantle source and was later followed by Lasail Unit magmatism in seamount spreading centers in the off-axis settings away from the axial Geotimes volcanism. This is supported by the coexistence of the Geotimes and Lasail Units lavas interlayered as in northern blocks (e.g., Fizh, Salahi and others), which were not shown or explained in their discussions.
Ernewein et al. (1988) suggested that V1 lavas magmatism initiated in the mid-oceanic ridge axis and was followed by intra-oceanic volcanism as a result of oceanic rifting that produced two suites from more primitive to more evolved lavas. This is also supported by the fact that the calculated chondrite-normalized REE patterns of the liquids in equilibrium with the layered gabbros were more depleted in LREE $(\mathrm{La}-\mathrm{Nd})$ than the actual abundances of the chondrite-normalized REE patterns of the V1 lavas. In addition to that, there is the lack of calculated chondrite-normalized REE patterns of the liquids in equilibrium with the plutonic intrusives, which are cogenetic with the V2 lavas in their mantle sources. The non-possibility of this is principally due to the lack of the adcumulus texture, which indicates the equilibrium textures. Both of these latter pieces of evidence are related to the disequilibrium processes, which do not follow the fractionation trends of lavas and their precursor sheeted dikes, as was clearly shown in Adachi et al. (2003) and Miyashita et al. (2003). In addition, V2 (type 1) lavas are interlayered within V1 lavas, as demonstrated in Ghayth area where V1 lavas match with Unit 1a and V2 (type 1) lavas match with Unit $1 \mathrm{~b}$. This interlayered phenomenon is also noticed elsewhere in other northern blocks, such as Salahi and others, and was not mentioned or explained in Ernewein et al. (1988).

Umino et al. (1990) suggested that Geotimes Volcanics (which link both Units 1a and 1b) formed in the mid-ocean ridge volcanism over an open system magma chamber. This is followed by the subduction suite or Alley Volcanics. However, the trace element systematics and 


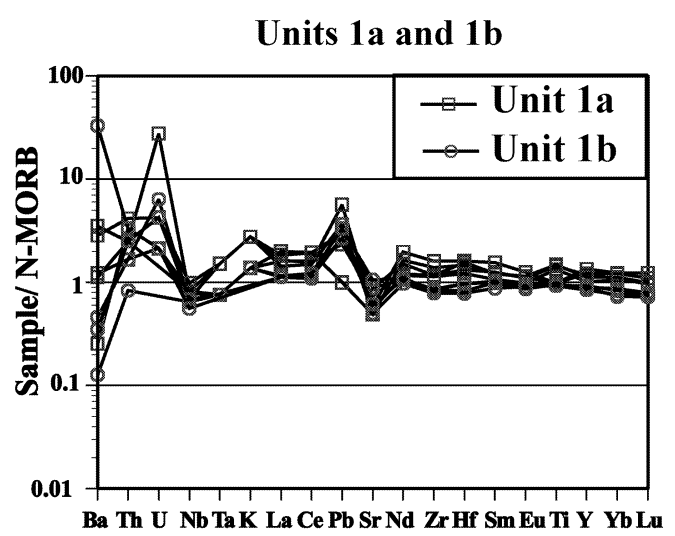

Naturaliste and Southern Plateau lavas

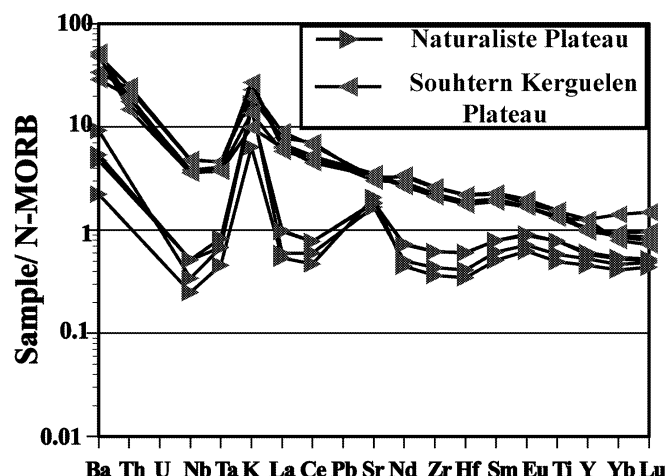

East Pacific Rise lavas at $10^{\circ} 30^{\prime}$

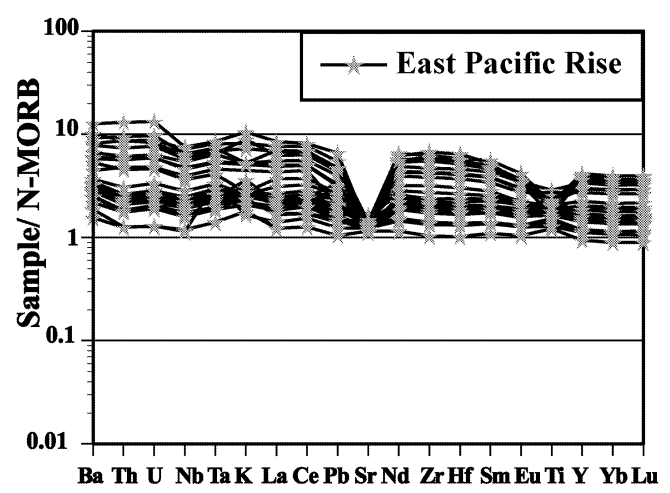

Lavas from Godard et al., 2003

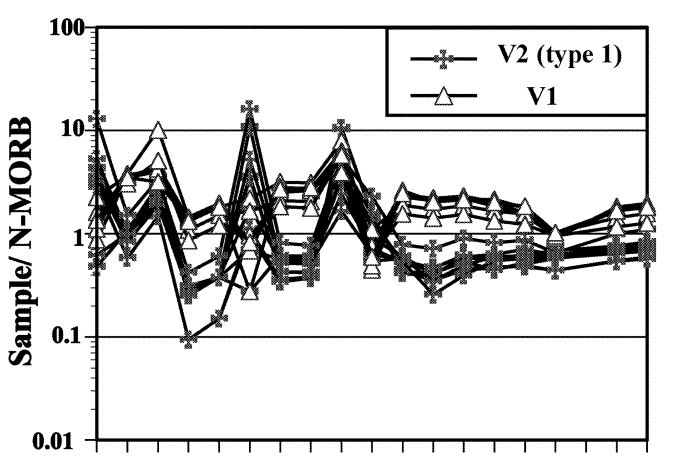

Ba Th U NbTa K La Ce PbSr Nd ZrHf SmEuTi Y YbLu
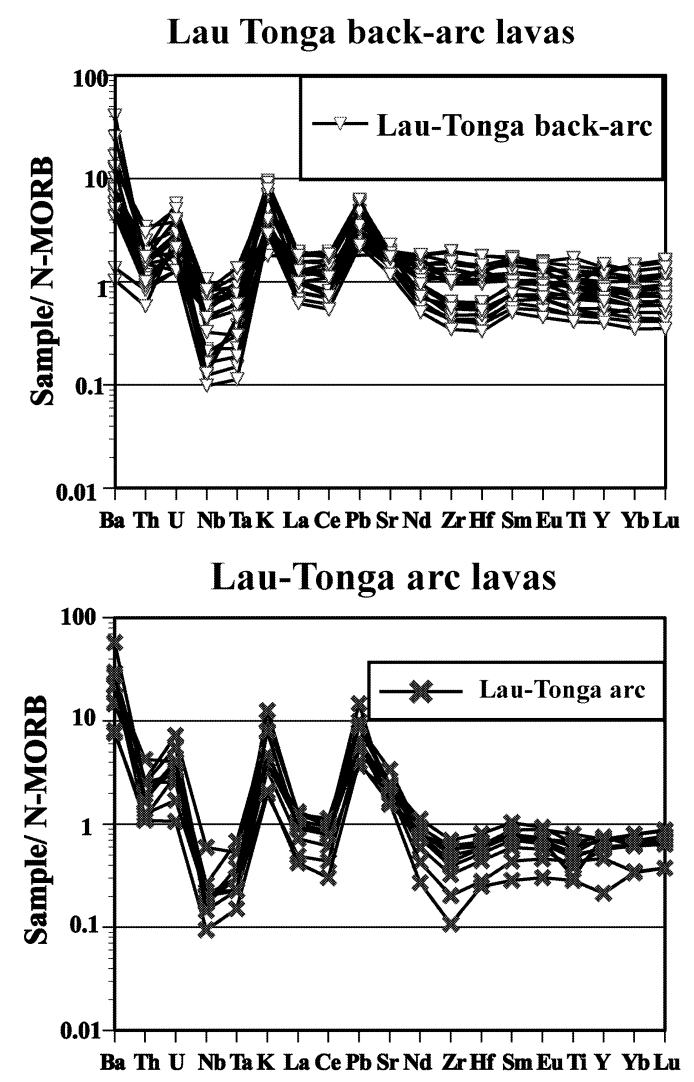

Izu-Bonin fore-arc lavas

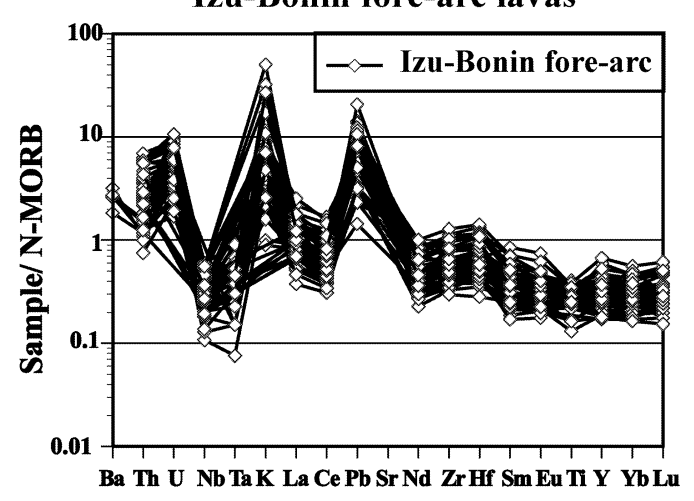

Figure 12. Spider diagrams of Units 1a and 1b and in comparison with other lavas in different tectonic settings (Ewart et al., 1994; Godard et al., 2003; Mahoney et al., 1995; Murton et al., 1992; Regelous et al., 1999). 

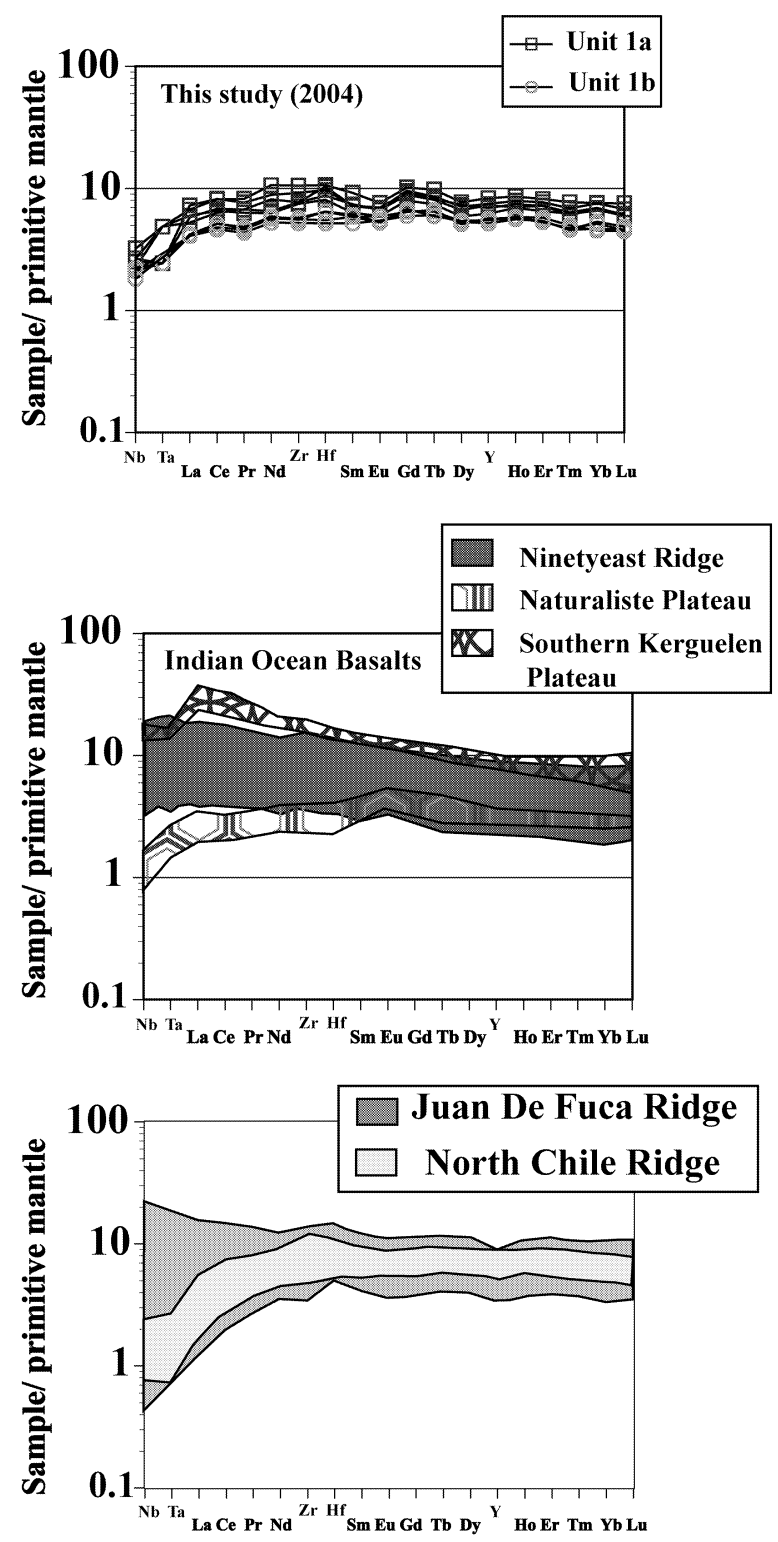

Figure 13. Trace elements patterns normalized to primitive mantle (Sun and McDonough, 1989) compared with different tectonic environments (Frey et al., 1991; Van Wagoner et al., 1991; Mahoney et al., 1995; Bach et al., 1996).

patterns in Figures 10, 12 and 13 show depletion in high field-strength elements relative to N-MORB (especially $\mathrm{Nb}$ and $\mathrm{Ta}$ ) in Unit 1a or Geotimes Volcanics, which makes such a model doubtful.

Figure 12 shows spider diagram patterns of selected HFSE with LILE compared with their close analogous tectonic environments such as the East Pacific Rise, LauTonga back-arc and fore-arc lavas and both Kerguelen and Naturaliste Plateaus. In addition, the lava compositions of Godard et al. (2003) were added to the set of spider diagram patterns to be a reference for Units $1 \mathrm{a}$ and $1 \mathrm{~b}$ as they are considered to be less altered than Units 1a and $1 \mathrm{~b}$. The spider diagram patterns of Units $1 \mathrm{a}$ and $1 \mathrm{~b}$ shows a similarity with the East Pacific Rise at $10^{\circ} 30^{\prime}$ which represents as an analog for N-MORB affinity, except for the depletions in $\mathrm{Nb}$ and $\mathrm{Ta}$. Also, these patterns show a close similarity with the Naturaliste Plateau, which was contaminated by the nearby rifted continental margin. However, we have no evidence for that in Units 1a and $1 \mathrm{~b}$. These diagrams also show a close similarity with the Lau-Tonga back-arc basin lava patterns noted by Ewart et al. (1994) with Units 1a and 1b, especially in respect of the $\mathrm{Nb}$ and $\mathrm{Ta}$ depletions. Also, the Units $1 \mathrm{a}$ and $1 \mathrm{~b}$ can be differentiated from the Lau-Tonga back-arc basin diagrams by the slightly elevated patterns of Units $1 \mathrm{a}$ and $1 \mathrm{~b}$. This can be explained by the mixing nature of these lavas between back-arc basin and N-MORB affinities. This phenomenon is also seen in the Lau-Tonga back-arc system in that the Eastern Lau Spreading Center exhibits a spectrum in compositions from more MORB-like chemistry at its north end to more arc-like chemistry at its southern end where it converges on the Tofua Arc (Ewart et al., 1994).

\section{CONCLUSIONS}

The magmatic history, as expressed in the volcanic units in the Ghayth area, reveals a complex, multistage sequence of lavas, which provides some information on the processes associated with the formation and evolution of the local ocean floor. The geochemical signatures of Units $1 \mathrm{a}$ and $1 \mathrm{~b}$ show that they originated from same mantle source but enjoyed eruptive fractionation events to different degrees, as evidenced by the plots of $\mathrm{Mg \#}$ and $\mathrm{Zr}$ versus other major, minor and trace elements. Incompatible trace element abundances in both Units $1 \mathrm{a}$ and $1 \mathrm{~b}$ are similar to N-MORB but show slight depletions in HFSEs especially $\mathrm{Nb}$ and Ta. Several examples from different tectonic environments, such as the Northern Chile Ridge, the Juan De Fuca Ridge and the Ninetyeast Ridge and also the southern Kerguelen and Naturaliste Plateaus of the Indian Ocean were demonstrated and discussed in respect of their petrogenetic characteristics and the correlation of their magmatic histories in comparison with Units 1a and 1b. Also, several authors suggested variable petrogenetic models of the Oman ophiolite extrusives, depending on the lava morphologies and geochemistries, and these were examined in this paper. However, the mildly depleted to flat LREE ( $\mathrm{La}-\mathrm{Nd}$ ) coupled with the depletions of $\mathrm{Nb}$ and Ta relative to N-MORB values in Units $1 \mathrm{a}$ and $1 \mathrm{~b}$ of the Ghayth area are related to the mixing compositions between N-MORB and arc and/or back-arc basin basalts. Thus, these lavas are contami- 
nated by both affinities. This indicates to us the setting to be more likely in a back-arc basin spreading center, as compared with Lau Tonga back-arc and arc systems. This is also evidenced by the fact that the Oman ophiolite was proposed to have been formed over depleted mantle, which contaminated it with fluid-enriched melts (Pearce et al., 1981; Alabaster et al., 1982; Pearce et al., 1984; Lippard et al., 1986; Peate and Pearce, 1998; Godard et al., 2003).

\section{ACKNOWLEDGMENTS}

The fieldwork was given a great support by Dr. Hilal AlAzri, who is in the Directorate General of Minerals, Ministry of Commerce and Industry, Sultanate of Oman. I would like to thank Mrs. Shibata and Kajima from Mitsubishi Materials for the field guidance. Thanks to Professor D.H. Green from Hokkaido University Museum for his review of the manuscript. Fruitful discussions were held with Drs. Maeda, Ueda and Yamazaki of Hokkaido University that materially improved this manuscript. Deep scientific discussions, both efficient and successful, were held with Professor T. Mizuta of Akita University. Great thanks to Dr. M. Ogasawara of the Geological Survey of Japan for his practical and scientific support. I am very grateful to my colleagues in Niigata and Hokkaido Universities for their unlimited support. Careful readings of the manuscript and constructive reviews by an anonymous reviewer were very helpful. We also thank Professor M. Arima for his suggestions and editorial handling. This research was supported in part by a 21 st Century Center of Excellence (COE) Program on "Neo-Science of Natural History" (Program Leader: Hisatake Okada) at Hokkaido University granted by the Ministry of Education, Culture, Sports, Science and Technology, Japan.

\section{REFERENCES}

Adachi, Y. and Miyashita, S. (2003) Geology and petrology of the plutonic complexes in Wadi Fizh area: Multiple magmatic events and segment structure in the northern Oman ophiolite. Geochemistry, Geophysics and Geosystems, 4, doi: 10.1029/ $2001 \mathrm{GC} 000272$.

Alabaster, T., Pearce, J.A. and Malpas, J. (1982) The volcanic stratigraphy and petrogenesis of the Oman ophiolite Complex. Contributions to Mineralogy and Petrology, 81, 168-183.

Bach, W., Erzinger, J., Dosso, L., Bollinger, C., Bougault, H., Etoubleau, J. and Sauerwein, J. (1996) Unusually large $\mathrm{Nb}^{-}$ Ta depletions in North Chile Ridge Basalts at $36^{\circ} 50^{\prime}$ to $38^{\circ} 56^{\prime} \mathrm{S}$ : major element, trace element, and isotopic data. Earth and Planetary Science Letters, 142, 223-240.

Beurrier, M. (1987) Geologie de la nappe ophiolitique de Samail dans les parties orientales et centrales des montagnes d'Oman. Universite Pierre et Marie Currie, Paris VI, Paris, France.
Bonatti, E. and Harrison, C.G.A. (1988) Eruption styles of basalt in oceanic spreading ridges and seamounts: Effect of magma temperature and viscosity. Journal of Geophysical Research, 93, 2967-2980.

Cabanis, B. and Lecolle, M. (1989) Le Diagramme La/10-Y/15$\mathrm{Nb} / 8$ : un outil pour la discrimination des series volcaniques et la mise en evidence de processus de mélange et/ ou de contamination crustale. Comptes Rendus de l'Académie des Sciences de Paris, Série II, 309, 2023-2029 (in French with English abstract).

Doucet, S., Weis, D., Scoates, J.S., Debaille, V. and Giret, A. (2004) Geochemical and $\mathrm{Hf}-\mathrm{Pb}-\mathrm{Sr}-\mathrm{Nd}$ isotopic constraints on the origin of the Amsterdam-St. Paul (Indian Ocean) hotspot basalts. Earth and Planetary Science Letters, 218, 179-195.

Einaudi, F., Godard, M., Pezard, P., Cocheme, J.-J., Coulon, C., Brewer, T. and Harvey, P. (2003) Magmatic cycles and formation of the upper oceanic crust at spreading centers: Geochemical study of a continuous extrusive section in the Oman ophiolite. Geochemistry, Geophysics and Geosystems, 4, doi: 10.1029/2002GC00362.

Ernewein, M., Pflumio, C. and Whitechurch, H. (1988) The death of an accretion zone as evidenced by the magmatic history of the Sumail ophiolite (Oman). In the Ophiolites of Oman (Boudier F. and Nicolas A. Eds.). Tectonophysics, 151, 247274.

Ewart, A., Bryan, W.B., Chappell, B.W. and Rudnick, R.L. (1994) Regional geochemistry of the Lau-Tonga arc and backarc systems. Proceeding of the Ocean Drilling Program, Scientific Results, College Station, Texas, USA, 135, 385-425.

Frey, F., Jones, W., Davies H. and Weis, D. (1991) Geochemical and petrologic data for basalts from sites 756, 757, and 758: Implications for the origin and evolution of Ninetyeat Ridge. Proceedings of the Ocean Drilling Program, Scientific Results, Texas, USA, 121, 611-659.

Gill, J.B. (1981) Orogenic andesites and plate tectonics. pp. 385, Springer-Verlag, New York, USA.

Gillis, K.M. and Banerjee, N. (2000) Hydrothermal alteration patterns in supra-subduction zone ophiolites. In Ophiolites and Oceanic Crust: New insights from field studies and the Ocean drilling program. Boulder, Colorado, Geological Society of America, Special paper 349, 283-297.

Godard, M., Dautria, J.-M. and Perrin, M. (2003) Geochemical variability of the Oman ophiolite lavas: Relationship with spatial distribution and paleomagnetic directions. Geochemistry, Geophysics and Geosystems, 4, doi: 10-1029/2002 GC000452.

Ishikawa, T., Nagaishi, K. and Umino, S. (2002) Boninitic volcanism in the Oman ophiolite: Implications for thermal condition during transition from spreading ridge to arc. Geology, 30, 899-902.

Leterrier J., Maury R.C., Thonon P., Girard D. and Marchal M. (1982) Clinopyroxene composition as a method of identification of the magmatic affinities of palaeo-volcanic series. Earth and Planetary Science Letters, 59, 139-154.

Lippard, S. J., Shelton, A. W. and Gass, I.G. (1986) The ophiolite of Northern Oman, Memoir No.11. pp. 178, published for the Geological Society by Blackwell Scientific Publications, London.

Mahoney, J.J., Jones W.B., Frey, F.A., Salters, V.J.M., Pyle, D.G. and Davies, H.I. (1995) Geochemical characteristics of lavas from Broken Ridge, the Naturaliste Plateau and southernmost Kerguelen Plateau: Cretaceous plateau volcanism in the 
southeast Indian Ocean. Chemical Geology, 120, 315-345.

Miyashita, S., Adachi, Y. and Umino, S. (2003) Along-axis magmatic system in the northern Oman ophiolite: Implications of compositional variation of the sheeted dike complex. Geochemistry, Geophysics and Geosystems, 4, doi: 10.1029/ $2001 \mathrm{GC} 000235$.

Morimoto, Fabries, N.J., Ferguson, A.K., Ginzburg, I.V., Ross, M., Seifert, F.A., Zussman, J., Aoki, K. and Gottardi, G. (1988) Nomenclature of pyroxenes. American Mineralogist, 52, 535-550.

Murton, B.J., Peate, D.W., Arculus, R.J., Pearce J.A and Van der Laan, S. (1992) Trace element geochemistry of volcanic rocks from site 786: The Izu-Bonin forearc. Proceeding of the Ocean Drilling Program Scientific Results, College Station, Texas, USA, 125, 211-235.

Regelous, M., Niu, Y., Wendt, J.I., Batiza, R., Greig, A. and Collerson K.D. (1999) Variations in the geochemistry of magmatism on the East Pacific Rise at $10^{\circ} 30^{\prime} \mathrm{N}$ since $800 \mathrm{ka}$. Earth and Planetary Science Letters, 168, 45-63.

Pearce, J.A. and Cann, J.R. (1971) Ophiolite origin investigated by discriminant analysis using $\mathrm{Ti}, \mathrm{Zr}$ and $\mathrm{Y}$. Earth and Planetary Science Letters, 12, 339-349.

Pearce, J.A. and Cann, J.R. (1973) Tectonic setting of basic volcanic rocks determined using trace element analyses. Earth and Planetary Science Letters, 19, 290-300.

Pearce, J.A., Alabaster, T., Shelton, A.W. and Searle, M.P. (1981) The Oman ophiolite as a cretaceous arc-basin complex: Evidence and implications. Philosophical Transactions of the Royal Society of London, Series A, 300, 299-317.

Pearce, J.A., Lippard, S.J. and Roberts, S. (1984) Characteristics and tectonic significance of supra-subduction zone ophiolites. In Marginal basin geology: volcanic and associated sedimentary and tectonic processes in modern and ancient marginal basins (Kokelaar, (B.P. and Howells, M.F. Eds.). pp. 322, Geological Society Special Publication 16, London, UK, 77-94.

Pearce, J.A. and Peate, D.W. (1995) Tectonic implications of the composition of volcanic arc magmas. Annual Reviews of Earth and Planetary Science, 23, 251-285.

Peate, D.W. and Pearce, J.A. (1998) Causes of spatial compositional variations in Mariana Arc lavas: Trace element evi- dence. The Island Arc, 7, 479-495.

Plank, T. and Langmuir, C.H. (1993) Tracing trace elements from sediment input to volcanic output at subduction zones. Nature, 362, 739-742.

Plank, T. and Langmuir, C.H. (1998) The chemical composition of subducting sediment and its consequences for the crust and mantle. Chemical Geology, 145, 325-394.

Rochette, P., Jenatton, L., Dupuy, C., Boudier, F. and Reuber, I. (1991) Diabase dikes emplacement in the Oman Ophiolite: A magnetic fabric study with reference to geochemistry. In Ophiolite Genesis and Evolution of the Oceanic Lithosphere (Peters T. et al. Eds.). pp. 912, Ministry of Petroleum And Minerals, Muscat, Sultanate of Oman, 55-82.

Sun, S.S and McDonough, W.F. (1989) Chemical and isotopic systematics of oceanic basalts: Implications for mantle composition and processes. In Magmatism in the Ocean Basins (Saunders A.D. and Norray M.J. Eds.). pp. 398, Geological Society of London Special Publication 42, London, UK, 313-345.

Takahashi, T. and Shuto K. (1997) Major and trace element analyses of silicate rocks using X-ray fluorescence spectrometry RIX3000, Rigaku-Denki Journal, 28, 25-37 (in Japanese).

Umino, S., Yanai, S., Jaman, A.R., Nakamura, Y. and Iiyama J.T. (1990) The transition from spreading to subduction: Evidence from the Semail ophiolite, northern Oman mountains. In Ophiolites: Oceanic Crustal Analogues (Malpas, J. et al. Eds.). Geological Survey Department, Ministry of Agriculture and Natural Resources, Nicosia, Cyprus, 375-384.

Van Wagoner, N.A. and Leybourne, M.I. (1991) Evidence for magma mixing and a heterogeneous mantle on the West Valley Segment of the Juan de Fuca Ridge. Journal of Geophysical Research, 96, B10, 16295-16318.

Winchester, J.A. and Floyd, P.A. (1976) Geochemical magma type discrimination; application to altered and metamorphosed basic igneous rocks. Earth and Planetary Science Letters, 28, 459-469.

Manuscript received November 2, 2004

Manuscript accepted May 9, 2005

Manuscript handled by Makoto Arima 